\title{
Ubiquitin, SUMO and Nedd8 as therapeutic targets in cancer
}

Authors:

Pierre Gâtel, Marc Piechaczyk and Guillaume Bossis

Affiliations:

Equipe Labellisée Ligue Contre le Cancer, Institut de Génétique Moléculaire de Montpellier, University of Montpellier, CNRS, Montpellier, France

Correspondence to:

guillaume.bossis@igmm.cnrs.fr

Phone: 0033434359671

Fax: 0033434359634

Conflict of interest:

The authors declare no conflict of interest 


\begin{abstract}
Ubiquitin defines a family of approximately 20 peptidic post-translational modifiers collectively called the Ubiquitin-like (UbLs). They are conjugated to thousands of proteins, modifying their function and fate in many ways. Dysregulation of these modifications has been implicated in a variety of pathologies, in particular cancer. Ubiquitin, SUMO (-1 to -3) and Nedd8 are the bestcharacterized UbLs. They have been involved in the regulation of the activity and/or the stability of diverse components of various oncogenic or tumor suppressor pathways. Moreover, the dysregulation of enzymes responsible for their conjugation/deconjugation has also been associated with tumorigenesis and cancer resistance to therapies. The UbL system therefore constitutes an attractive target for developing novel anticancer therapeutic strategies. Here, we review the roles and dysregulations of Ubiquitin-, SUMO- and Nedd8 pathways in tumorigenesis, as well as recent advances in the identification of small molecules targeting their conjugating machineries for potential application in the fight against cancer.
\end{abstract}




\section{Introduction}

Ubiquitin is the founding member of a polypeptide family of approximately 20 protein posttranslational modifiers [1]. For the sake of simplicity, these, together with Ubiquitin, will be called the Ubiquitin-likes, or UbLs, hereafter. Among them, Ubiquitin, Nedd8 and the 3 members of the SUMO family (SUMO-1 to -3) are at the heart of this review.

UbLs are small globular polypeptides of 8 to $12 \mathrm{kDa}$. They share low sequence similarity but high structural identity with one $\alpha$-helix and five $\beta$-sheets ( $\beta$-grasp fold) followed by a $C$ terminal tail [2]. In most cases, they are covalently conjugated to proteins via formation of an isopeptide bond between their C-terminal glycine and the $\varepsilon-\mathrm{NH}_{2}$ group of lysines from substrates. Nevertheless, other, quantitatively minor, conjugations of Ubiquitin to other amino acid residues or at the $\mathrm{N}$-terminus of proteins have been described.

The mechanisms of conjugation are very similar amongst the UbLs even though each one of them is transferred to protein substrates using specific sets of enzymes. Yet, certain of these enzymes can intervene in the conjugation of more than one UbL type under certain conditions (Table 1). As UbL conjugation/deconjugation processes have been described extensively in a number of reviews [3, 4], they will only be addressed briefly below. UbLs are first activated by UbLactivating enzymes called E1s. These use ATP to form a thioester bond between the UbL Cterminal glycine and their catalytic cysteine. The C-terminal glycine is then trans-thiolated, allowing the UbL to be transferred onto the catalytic cysteine of UbL-conjugating enzymes called E2s. Although E1s and E2s can, in some cases, be sufficient to conjugate certain UbLs on target proteins, they most often require a third factor called E3 [5, 6]. More than 600 E3s have been proposed for Ubiquitin, but much less for the other UbLs. Certain E3s can be full-blown enzymes. This is the case of the E3 Ubiquitin ligases from the HECT family, which harbor catalytic cysteines forming thioester bonds with the Ubiquitin C-terminal glycine before transfer of Ubiquitin onto protein substrates. However, in most cases, E3s function as mere adaptors between E2s and substrates to confer reaction selectivity. Certain UbLs can be conjugated to themselves via the formation of isopeptide bonds between their C-terminal glycines and certain of their own lysines. This is especially true for ubiquitin, which can form chains involving each one of its seven lysines (K6, K11, K27, K29, K33, K48, K63). These chains can be homotypic or heterotypic due to the multiplicity of conjugatable lysines on Ubiquitin [7]. Mixed chains between different UbLs can also be formed. The best-known ones are those between Ubiquitin and SUMO or Nedd8 [8]. Importantly, UbL conjugation is reversible and highly dynamic with 
most substrates being constantly modified and demodified. Deconjugation is carried out by isopeptidases, which cleave the isopeptide bonds between UbLs and target lysines. This allows UbLs, which are highly stable polypeptides, to be recycled and reconjugated to other proteins. Some isopeptidases are also involved in the proteolytic maturation of UbLs, which are synthetized in the form of precursors displaying extra amino-acids at their C-termini. Similar to $\mathrm{E} 3 \mathrm{~s}$, isopeptidases show substrate specificity or, at least, preference for particular chain linkages [9]. Concerning the SUMO pathway, deSUMOylases, such as SENP6 and SENP7, preferentially cleave SUMO-2 chains, whilst others, such as SENP-1 and SENP-2, rather deconjugate SUMO bound to target proteins [10]. Some deSUMOylases such as SENP-3, SENP-5 and USPL1 have preference for SUMO-2 over SUMO-1 [11, 12].

The consequences of UbL conjugation are numerous. They depend on the UbL type, possibly the nature of $\mathrm{UbL}$ chains formed and, obviously, the substrate. As they have been reviewed extensively elsewhere [3, 13-15], only the main physiological roles of Ubiquitylation, SUMOylation and Neddylation are considered hereafter.

The biological outcomes of Ubiquitin conjugation are highly dependent on the chain linkage types, which, due to their diversity and complexity, create the so-called "Ubiquitin code" [14]. The most abundant and best-characterized Ubiquitin chains are long K48-linked ones (>4 Ubiquitins). They constitute a protein degradation signal recognized by the $26 \mathrm{~S}$ proteasome, which is the main cell proteolytic machinery [16-18]). This discovery led Avram Hershko, Irwin Rose an Aaron Ciechanover to be awarded the Nobel Prize in 2004. It is, however, important to keep in mind that K48-linked Ubiquitin chains can also be involved in signaling events and transcription regulation not involving protein destruction [19-21]. K63-linked chains are bestknown as involved in protein-protein interactions, signaling, inflammatory response, DNA repair and ribosomal function $[8,22,23]$. K11 chains were shown to play important roles in cell cycle regulation and the activation of the $\mathrm{NK}-\kappa \mathrm{B}$ pathway [24, 25]. Moreover, Ubiquitin can also form linear head-to-tail chains when its C-terminal glycine is linked to the N-terminal methionine of another Ubiquitin $[26,27]$. Such chains are formed by the LUBAC complex and play key roles in immune signaling [28]. Finally, Ubiquitin can also be conjugated to protein substrates as monomers, sometimes at multiple sites, to regulate transcription, DNA repair or membrane receptor internalization and possibly degradation [29-31].

More than 6,000 SUMOylated proteins have been identified recently thanks to proteome-wide mass spectrometry approaches $[32,33]$. SUMOylation modifies the surface of target proteins and, 
thereby, alter their function and fate. In particular, SUMO can recruit $\underline{S} U M O-\underline{i n t e r a c t i n g}$ motifs (SIM)-bearing proteins. However, only a handful of such effectors of SUMOylation have been

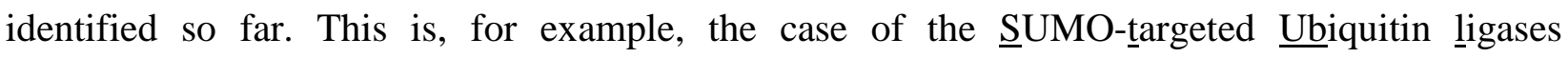
(StUBLs). These proteins, which include RNF4 [34, 35] and Arkadia/RNF111 [36] harbor multiple SIMs recognizing poly-SUMO-2 chains irrespectively of the substrate they are bound to. As the interaction between SUMO and SIMs is of low affinity, SUMOylation most often stabilizes an already existing interaction rather than promotes a new one. This is typically illustrated by the binding of the DNA helicase Srs2 to SUMO-modified PCNA [37]. Albeit SUMO has been involved in many cellular processes, its best-described functions are nuclear, consistently with a higher accumulation of SUMOylated proteins in the nucleus. In particular, SUMOylation plays key roles in DNA damage repair through the modification of critical proteins involved in this process [38]. SUMO also modifies a high number of proteins involved in gene expression (transcription factors, co-regulators, histones, transcription machinery) and participates in the regulation of transcription [39-43]. SUMOylation often concerns protein complexes comprising multiple SUMOylatable subunits. In this case, the biological outcomes are usually thought to result from SUMOylation of the complex irrespective of the SUMOylation site or of the SUMOylated proteins within the complexes [44]. SUMOylation is highly regulated by stresses [45]. Some stresses affect limited number of SUMO substrates, while others can alter the activity of the whole pathway by affecting SUMO-conjugating- and/or -deconjugating enzymes. For example, upon proteotoxic stress induced by heat shock, SUMO-2 conjugation is quantitatively rewired to chromatin-bound proteins [46], which prevents protein aggregation and targets them for degradation by the Ubiquitin-proteasome system [47]. Oxidative stress is also a critical regulator of SUMOylation through its ability to induce the reversible inactivation of the SUMO E1 and E2 via the formation of a disulfide bond between their catalytic cysteines [48]. This redox regulation of SUMOylation participates in the activation of ATM kinase and is required for proper DNA damage response [49]. Reactive Oxygen species have also been involved in the regulation of specific SUMO E3 and isopeptidases [50].

Nedd8 (Neural precursor cell-expressed developmentally down-regulated 8) is the closest kin of Ubiquitin, as they share $60 \%$ of homology. Cullins, which are key components of the family of

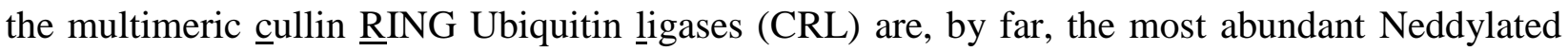
proteins. Cycles of Neddylation/deNeddylation are required for their Ubiquitin ligase activity [51]. Nedd8 is also conjugated to many non-cullin substrates [15]. These include transcription factors, such as p53 [52], TAp73 [53] and E2F1 [54, 55], as well as the VHL (Von-Hippel- 
Lindau)[56], BCA3 (Breast-Cancer-Associated protein 3)[57], the chemokine receptor CXCR5 [58] and several ribosomal proteins [59-62]. In these cases, Neddylation is involved in their localization, stabilization or regulation of their interaction with partners [15]. Similarly to SUMOylation, Neddylation has also been implicated in the response to proteotoxic stresses [63].

\section{Oncogenic and tumor suppressor pathways are controlled by UbLs}

UbLs, through the variety of proteins they conjugate, are involved in each one of the "Hallmarks of cancer", as defined by Hanahan and Weinberg [64]. For reasons of space, it is impossible to summarize here all cancer-relevant pathways regulated by UbLs. The reader is, therefore, referred to recent comprehensive reviews on this subject $[65,66]$. Below, we will focus only on pathways that are controlled by at least two UbLs.

\section{The p53 pathway}

The tumor suppressor protein p53 is certainly the best-studied transcription factor in cancer where its major cell protection functions are most often, if not always, lost. Physiologically, p53 participates in multiple cellular functions. They non-exhaustively include regulation of cell cycle and death, senescence, autophagy, DNA damage repair and metabolism. p53 is mutated in approximately $50 \%$ of tumors, where its mutations can be associated with oncogenic gains of function. In most of the other tumors, either the p53 gene is deleted or its activity, or that of its protein product, is inhibited following a diversity of mechanisms, which results in inability to control cell proliferation or to induce apoptosis or senescence [67].

The first and best-characterized p53 modification by UbLs is Ubiquitylation [68]. The main cellular E3 ligase for p53 is the MDM2 protein, which maintains low p53 levels under basal conditions via K48-linked chain Ubiquitylation and subsequent proteasomal degradation [69, 70]. Upon genotoxic stress, for example, this Ubiquitylation is arrested, permitting p53 to accumulate and to exert its cell protection functions. On the contrary, upon hyperactivity or amplification of the pro-oncogenic MDM2 gene, p53 is continuously maintained at a low level, favoring tumorigenesis [71]. A similar pro-oncogenic p53 inactivation process occurs in human papilloma virus (HPV) 16/18-infected cervix epithelial cells where the p53-interacting viral protein E6 recruits the cellular E6AP HECT E3 ligase [72, 73]. Interestingly, MDM2 can also monoUbiquitylate p53, which entails nuclear export and, thereby, inhibition of transcriptional activity [74]. Such a cytosolic export also impacts other p53 functions, including inhibition of autophagy and induction of apoptosis [75]. Other E3 Ubiquitin ligases such as MSL2 [76] and WWP1 [77] 
were shown to target p53 to the cytosol without, however, affecting its proteasomal degradation. Finally, the E3 ligase E4F1 was reported to Ubiquitylate p53 on chromatin. E4F1 increases p53 ability to activate specific transcriptional programs related to cell cycle arrest without affecting its degradation [20](Figure 1)

p53 activity can also be controlled by Neddylation, which involves the E3 ligases activities of MDM2 [52], as well as that of FBOX11 [78]. Neddylation occurs on 3 lysines $(370,372,373)$ and reduces p53 transcriptional activity [52, 78-80]. In addition, p53 Neddylation was shown to limit its Ubiquitin-mediated nuclear export [79].

Finally, p53 can also undergo modification by SUMO on its lysine 386 [81-83]. However, the role of this SUMOylation is still debated and might depend on the cellular context [84]. Indeed, p53 SUMOylation was initially described to increase its transcriptional activity [81, 82]. However, other studies showed that SUMOylation is involved in neither p53 localization nor transcriptional activity [85]. SUMOylation was also suggested to regulate p53 subcellular localization. For example, SUMOylation of mouse p53 was shown to be required for nuclear accumulation and enhanced stability in granulosa cells [86]. However, and contrasting with the latter observation, androgen-mediated SUMOylation of p53 was suggested to be important for export of p53 to the cytosol [87] (Figure 1).

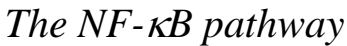

The NF- $\kappa \mathrm{B}$ pathway is overactive in a vast majority of cancers where it is thought to participate in cancer cell resistance to apoptosis and sustained proliferation. This is especially true in hematological malignancies, where the function of various components of this pathway can be altered, notably by oncogenic mutations or rearrangements/translocations [88].

Under basal physiological conditions, the NF- $\kappa \mathrm{B}$ transcription factor is maintained latent in the cytoplasm through physical interaction with its $\mathrm{I} \kappa \mathrm{B} \alpha$ inhibitor [89]. Ubiquitylation is involved in its activation at several steps. A typical example of NF- $\kappa \mathrm{B}$ pathway activation is as follows. In response to an appropriate extracellular stimulus, the RIPK1 (receptor-interacting serine/threonine protein kinase 1) kinase, is modified with non-proteolysis-inducing linear Ubiquitin chains by the LUBAC complex and K11- and K63-linked chains by the cIAP1 (cellular inihibitor of apoptosis protein-1) Ring domain-bearing Ubiquitin E3 factor. These Ubiquitylations serve as a platform for recruiting a downstream kinase effector complex (made up of TAK1, TAB2/3, IKK $\gamma / \mathrm{NEMO}$ ), which activates another kinase complex (IKK complex 
made up of $\mathrm{IKK} \alpha$ and $\mathrm{IKK} \beta$ ). Finally, the latter phosphorylates $\mathrm{IkB} \alpha$, which triggers its subsequent K48-linked Ubiquitylation and is followed by proteasomal degradation. The NF- $\kappa \mathrm{B}$ transcription factor is, thereby, released and can then enter the nucleus to activate its target genes [24].

In the early days of the SUMO field, it was discovered that SUMOylation of I $\mathrm{B} \alpha$ competes with Ubiquitylation by targeting the same lysine residue (Lys 21)[90]. SUMOylation is also involved in the regulation of NEMO activity. In particular, NEMO gets SUMOylated upon genotoxic stress. This leads to its addressing to the nucleus and subsequent ATM-dependent Ubiquitylation and activation of the IKK complex in the cytoplasm [91].

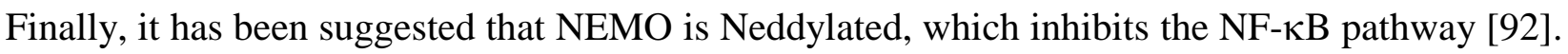
Neddylation was also involved in the regulation of NF- $\kappa \mathrm{B}$-dependent transcription through modification of BCA3, one of its partners in chromatin. BCA3 Neddylation recruits the deacetylase SIRT1 and, thereby, was proposed to repress transcription of NF- $\kappa$ B target genes [57].

\section{The TGF $\beta$ pathway}

The TGF- $\beta$ (Transforming Growth Factor $\beta$ ) pathway generally exerts tumor suppressor activity in normal or premalignant cells but, on the contrary, often promotes tumorigenesis at later stages, including metastasis. Depending on the cell/tumor type, it can be involved in the regulation of cell proliferation, apoptosis, epithelial-mesenchymal transition (EMT) and cell migration [93].

In the canonical pathway, the binding of TGF- $\beta$ to its cell membrane receptor (made up of two subunits, T $\beta$ R-I and T $\beta$ R-II) initiates a cascade of intracellular phosphorylation events. Among the first phosphorylated proteins are Smad-2 and Smad-3, which are transcription factors maintained latent in the cytoplasm in the absence of TGF- $\beta$ receptor activation. Phosphorylated Smad-2 and -3 then assemble with the Smad-4 protein to form a trimeric complex that translocates into the nucleus where it binds to DNA and stimulates the expression of TGF- $\beta$ target genes [94]. Interestingly, Ubls control this pathway at multiple and intermingled levels [95]. More specifically, Smad-7 is a cytoplasmic TGF- $\beta$-induced negative regulator of the pathway that can recruit Smurf-1 and Smurf-2 (Smad-specific E3 Ubiquitin ligase 1 and -2), two Ubiquitin ligases of the HECT family. These can Ubiquitylate T $\beta R$-I, leading to its degradation and, thereby, induce a negative feedback loop on the pathway [96, 97]. T $\beta$ R-I Ubiquitylation, and consequently its degradation, can, however, be antagonized by the deUbiquitylase Usp15, which 
associates with Smurf-2, and act as a positive regulator of the pathway [98]. Interestingly, Smurf1 and -2 are positively regulated by Neddylation via particular mechanisms. Indeed, Nedd8 is, first, transferred from the Nedd8-conjugating E2 enzyme Ubc12 to the catalytic cysteine of Smurf-1 via the formation of a thioester bond. It is, then, transferred to lysines of Smurf-1. This Neddylation increases the recruitment of Ubiquitin E2(s) and, thereby, activates the Ubiquitylation of Smurf-1 protein substrates [99]. Noteworthy, Smurf-1 and -2 were also shown to bind non-covalently to Nedd8, which also contributes to increasing their Ubiquitin ligase activity [100].

Complexifying the picture, SUMO can also enter into the game at different levels, as diverse components of the TGF- $\beta$ pathway can undergo SUMOylation with implications in cancer [101]. For example, SUMOylation of T $\beta$ R-I increases the activation of Smad-3 with, as a biological consequence, enhancement of invasion and metastasis by Ras-transformed cells [102] and suppression of EMT in bladder cancer cells [103]. Smurf-2 is also SUMOylated (on lysines 26 and 369) thanks to the SUMO ligase PIAS3, which increases its Ubiquitin ligase activity and, hence, the degradation of T $\beta R$-I. In this case, important outcomes of T $\beta R$-I proteolysis consist of decreased TGF- $\beta$-induced cell proliferation and reduced invasion by breast cancer cells [104, 105]. Transcription factors downstream of the TGF- $\beta$ pathway are also SUMOylated with sometimes antagonistic effects. For example, SnoN [106] and Sip1/Zeb2 [107] SUMOylations repress the pathway whereas those of Snail [108] and Slug [109] activate it. Finally, non-covalent SUMO binding might also be involved in the regulation of the TGF- $\beta$ pathway. As a matter of fact, the already mentioned SUMO-targeted Ubiquitin ligase Arkadia/RNF111 can be recruited via its cluster of SIMs (i.e. most probably due to binding to SUMO- 2 chains) to TGF- $\beta$ pathwaytarget genes with, as a result, antagonization of the Polycomb repressor complex at the level of their regulatory domains [110].

\section{PML-RARA in Acute Promyelocytic Leukemias}

Acute Promyelocytic Leukemias (APL) are a minor subtype $(<10 \%)$ of Acute Myeloid Leukemias. In most cases, their main driver tumorigenic mutations consists of a $t(15 ; 17)$ chromosomal translocation engaging the PML and RARA genes, leading to the expression of an oncogenic fusion PML-RAR $\alpha$. PML, which was initially viewed as a tumor suppressor, was one of the first SUMO substrates to be identified and is one of the most-abundantly SUMOylated proteins in the cell [111-113]. Through self-assembly, it forms the so-called membrane-less PML 
nuclear bodies, which recruit many proteins thanks to SUMO-SIM interactions. Recruited proteins can undergo SUMOylation in PML bodies due to the presence of the SUMO E2 Ubc9 within these structures (Sahin et al, 2014). Physiologically, PML bodies are seen as structures fine-tuning a variety of cellular activities that include responses to stresses and viral infections, as well as control of cell death, senescence or DNA repair. It has long been known that they are disrupted by the PML-RAR $\alpha$ fusion protein in APL cells [115], which is essential for oncogenesis. Interestingly, the combination of arsenic trioxyde and retinoic acid has been shown efficient at curing APL patients. Indeed, it consists of the first successful oncogenic proteintargeted therapy that has been described [116]. In brief, the drug combination entails the

polySUMOylation of PML-RAR $\alpha$, which is followed by the recruitment of the StUbl RNF4 and, hence, its Ubiquitylation and degradation by the proteasome [34, 35]. An important consequence of PML-RAR $\alpha$ destruction is not only induction of cancer cell differentiation into short-lived granulocytes but also abrogation of cancer cell self-renewal through the reformation of PML nuclear bodies and subsequent p53 pathway activation [117].

\section{Deregulations of UbL pathways in cancer}

\section{Many UbL enzymes are dysregulated in cancers}

Many enzymes and regulators of UbL-conjugating and -deconjugating pathways are dysregulated in various cancers (Table 2) and there is increasing evidence linking these dysregulations to tumorigenesis, cancer progression, metastasis or resistance to anticancer drugs. For reasons of space, it is not possible to describe all dysregulations that have been reported in the literature. Some illustrative examples are, however, summarized below.

\section{Dysregulation of the Ubiquitin pathway enzyme in cancer.}

The Ubiquitin pathway is far more complex than the SUMO and Nedd8 pathways, which increases the possibilities of dysregulations associated with cancer (Table 2). Two particularly illustrative examples of dysregulations of this pathway are presented below.

The first one concerns the BIRC1 to -8 (baculovirus_ IAP repeat-containing protein; IAP standing for inhibitors of apoptosis proteins) family of Ubiquitin E3 ligases. These enzymes play key roles in the activation of the NF- $\kappa \mathrm{B}$ pathway and the inhibition of apoptosis. Their overexpression appeared associated with increased resistance to therapies and adverse prognosis [118]. This is 
particular clear for BIRC4 (also called XIAP for X-linked inhibitor of apoptosis protein), which is overexpressed as early as the first stages of breast and colon carcinogenesis. This leads to inhibition of autophagy through the degradation of the autophagy receptor p62 and enhances tumor cell proliferation [119]. BIRC4 is also overexpressed in B-cell lymphomas and associated with weaker response to mitotic spindle poison-based chemotherapies. This is due to its increased stability resulting from its deUbiquitylation by the isopeptidase USP9X that is also overexpressed in the same tumors [120].

The second example deals with E3 ligases from the SCF (Skp1-Cullin1-F-box protein) family, which are also often dysregulated in cancer [121]. This is best-exemplified by various F-box proteins, which are the SCF components responsible for the specificity of substrate recognition [122]. For example, FBXW7 is a well-characterized tumor suppressor thanks to its ability to recruit oncogenic proteins such as c-Myc, c-Jun, c-Myb, Aurora-A for SCF-mediated Ubiquitylation and subsequent proteasomal degradation [123]. Consistently, disabling mutations of FBXW7 are found in numerous cancers. This is, for example, the case in $\underline{T}$-cell Acute Lymphocytic Leukemias (T-ALL), with up to $30 \%$ of patients presenting mutations in its gene [124] but also in colorectal adenocarcinoma, uterine endometrial carcinoma and bladder carcinoma. Skp2 is another F-Box protein dysregulated in many cancers [125]. Its substrates include the cell cycle inhibitor $\mathrm{p} 27^{\mathrm{Kip} 1}$. Its overexpression in many cancers is associated with a bad prognosis and is generally inversely correlated to $\mathrm{p} 27^{\mathrm{Kip} 1}$ expression [126]. The third F-Box, which is often dysregulated in cancer, is $\beta$-TRCP (also called FBW1A). It is overexpressed in various cancers, including colorectal tumors where it exerts prooncogenic actions through activating the $\beta$-catenin and NF- $\kappa \mathrm{B}$ pathways [127].

\section{Overactivation of the Nedd8 pathway in cancer is often associated with bad prognosis}

Strikingly, most enzymes of the Nedd8 pathway are overactivated in lung adenocarcinoma and squamous-cell carcinoma [128]. Along the same line, high Nedd8 expression is an adverse factor in nasopharyngeal carcinoma [99]. Moreover, the Nedd8-activating E1 (formed of the Nae1 and Uba3 subunits) and -conjugating E2 (Ubc12) enzymes were found upregulated in >2/3 of a 322 patient cohort with intra-hepatic cholangiocarcinoma, which was associated with higher global protein Neddylation and tumor progression [129]. Finally, the Jab1/CSN5 protein, which is responsible for deNeddylation of the members of the CRL family of Ubiquitin E3 ligases (see above), was found overexpressed in numerous cancers (breast cancer, ovarian cancer, hepatocellular carcinoma, non-small cell lung cancer, nasopharyngeal carcinoma, etc...) and 
associated with adverse prognosis [130].

Dysregulations of the SUMO pathway in cancer

Increasing evidence suggests that both SUMO conjugation- and deconjugation machineries are dysregulated in various cancers (Table 2). Yet, the contributions of these alterations to tumorigenesis have not often been established formally in most cases [65]. Interestingly, the level of Uba2, the catalytic subunit of the SUMO-activating E1 enzyme, is increased in colorectal cancer tissues, the highest Uba2 expression being associated with both the highest colorectal cancer stages and the poorest prognosis [131]. The SUMO-conjugating enzyme Ubc9 is also overexpressed in many cancers. This is the case of hepatocellular carcinomas, where its overexpression participates in the resistance to chemotherapies [132]. HyperSUMOylation has also been described in Myc oncogene-driven lymphomas. This results from a strong transcriptional activation of the expression of most enzymes of the SUMO pathway and is essential for tumorigenesis [133]. Using synthetic lethality screens, it was also shown that Mycoverexpressing breast cancer cells are highly dependent on a functional SUMO pathway for growth and survival [134], pointing to a novel therapeutic windows through targeting SUMOylation enzymes in this cancer type. Finally, deSUMOylases of the SENP family are either up- or down-regulated in cancers. SENP1 is, for example, overexpressed in prostate cancer, where it promotes tumor formation and metastasis [135] and downregulated in osteosarcomas, which is important for the maintenance of cancer stem cells [136].

\section{Targeting UbLs: new perspectives in cancer treatment}

Considering their critical roles and their widespread dysregulations in cancer, UbL pathways have emerged as promising therapeutic targets. Considerable efforts have consequently been made worldwide to develop strategies to inhibit their enzyme components [137]. We will focus here on the strategies used to target E1, E2 and E3 factors. For information on the targeting of deconjugating enzymes, the reader is referred to recent review [138, 139]

\section{E1 inhibitors}

- Ubiquitin E1 inhibitors

PYR-41 and PYZD-4409 were the first described inhibitors of an Ubiquitin-activating E1 enzyme. They are based on a pyrazolidine cycle and were identified during chemical library screenings [140, 141]. They bind to UBE1 and inhibit the formation of the thioester bond with Ubiquitin. Whether they inactivate UBA6, the second Ubiquitin E1, has however not been 
determined yet. PYZD-4409 was shown to induce apoptosis of Acute Myeloid Leukemia cells, with minimal toxicity for normal hematopoietic cells. It also displayed anti-tumoral activity in vivo in mice xenografted with human AMLs [140]. A more potent inhibitor of UBE1, TAK-243 (also known as MLN7243), was generated recently by Takeda Pharmaceuticals [142]. It forms an adduct with Ubiquitin and inhibits UBE1 in the nanomolar range. When used on cell lines, it leads to cell cycle arrest, induction of ER stress and impaired DNA damage response. Interestingly, TAK-243 showed (i) anti-tumor activity in vivo in immunodeficient mice subcutaneously grafted with various human tumor cell lines [142] and (ii) anti-leukemic activity on primary human AML cells both in vitro and in vivo after xenografting to immunodeficient mice (PDX) [143]. Finally, in a phase I dose-escalation clinical trial (clinicaltrial.gov identifier: NCT02045095) involving 29 patients with advanced solid tumors, it however, entailed serious adverse events in more than $1 / 3$ of the individuals treated. Its in vivo efficacy could be demonstrated by immuno-histochemistry using antibodies directed to either polyUbiquitin chains or Ubiquitylated-histone $\mathrm{H} 2 \mathrm{~B}$ ( $\mathrm{uH} 2 \mathrm{~B}$; which is the second most Ubiquitylated proteins in mammalian cells after Ubiquitylated $\mathrm{H} 2 \mathrm{~A}$ ). A second phase I trial is scheduled to start soon with patients undergoing relapse or suffering from hematological malignancies refractory to standard chemotherapies (clinicaltrial.gov identifier: NCT03816319)

- Nedd8 E1 inhibitors

MLN4924, also called TAK-924 or pevonedistat for its clinical form, is the first mechanismbased inhibitor of a UbL E1 enzyme that was designed by the Millenium-Takeda company. As TAK-243, MLK4924 is an ATP-competitive inhibitor of the Nedd8-activating E1 enzyme NAE. It forms a covalent adduct with Nedd8, which is catalyzed by NAE. The adduct cannot be transferred to Nedd8 E2s, blocking the activity of the E1, including in vivo [144]. Initial experiments showed that the treatment of immunocompromized mice xenografted with HCT-116 colon cancer cells with MLN4924 led to increased DNA-damage in cancer cells and limited tumor growth [145]. MLN4924 was then shown to have promising antitumoral activity in various preclinical cancer models, including patient-derived xenografts (PDX). Several phase I clinical trials in cancer patients have shown it is well tolerated [146-148] and various phase II trials have now been launched, in particular to treat hematological malignancies. MLN4924 was also shown to synergize, both in vitro and in vivo, with genotoxic drugs such as Cytarabine [149] or the demethylating agent Azacytidine [150] in AMLs. A phase Ib clinical trial in elderly patients unfit for conventional chemotherapies suggests a potential clinical benefit for the combination of Azacytidine and Pevonedistat [151]. A randomized phase III trial involving 450 patients with 
AML, CML (Chronic Myelomonocytic Leukemia) or MDS (Myelodysplastic syndrome) is now ongoing to prove the efficacy of this combination on a large scale (clinicaltrial.gov identifier: NCT03268954)

- SUMO E1 inhibitors

Ginkgolic acid was identified as an inhibitor of the SUMO-activating E1 enzyme during a screening using botanical extracts. This molecule, and its anacardic acid derivative, were shown to bind to the E1 and to inhibit the transfer of SUMO from the E1 to the E2 [152]. Anacardic acid was shown to inhibit cell division, to induce apoptosis and/or to inhibit migration of various cancer cell lines and primary samples [153-157]. It was also shown to limit tumor growth in mice xenografted with human KG1a AML cells [153]. However, anacardic acid is not a potent SUMOylation inhibitors, as it requires concentrations above $25 \mu \mathrm{M}$ to inhibit SUMOylation when used on cultured cells [152] and its use in preclinical models is unfortunately limited by its very poor solubility. Moreover, anacardic acid has been shown to inhibit various other enzymes, the best characterized one being the Histone Acetyl Transferase p300 [158]. Recently, Takeda Pharmaceutical has developed ML-792, a mechanism-based inhibitor of the SUMO E1 with nanomolar potency [159]. Similarly to the other UbL E1 inhibitors developed by Takeda Phamaceutical, it forms a covalent adduct with SUMO that is catalyzed by the SUMO E1. Treatment of cell lines with this inhibitor induces strong mitotic defects, which leads to their apoptosis. Interestingly, ML-792 preferentially affects the proliferation and viability of cancer cells overexpressing the Myc oncogene in vitro [159].

\section{E2 inhibitors}

Few inhibitors inhibiting UbL-conjugating E2 enzymes have been discovered so far and none of them is used in clinical trials yet.

The NSC697923 molecule was originally identified in a screen for molecules inhibiting the NF$\kappa \mathrm{B}$ pathway. It actually binds to the catalytic cysteine of the Ubc13-Uev1A Ubiquitin E2 that catalyzes the formation of K63-linked polyUbiquitin chains. Thereby, it prevents the formation of the thioester bond with Ubiquitin [160, 161]. This inhibitor limits the proliferation of diffuse large B-cell lymphoma cells in vitro [160]. BAY 11-7082, which was also initially reported as an inhibitor of the NF- $\mathrm{KB}$ pathway, was subsequently shown to inhibit K63-linked polyUbiquitin chains formation by targeting the catalytic cysteines of Ubc13 and $\mathrm{UbcH7}$ [162]. CC0651 is an allosteric inhibitor of the CDC34 Ubiquitin E2, which is associated with Ubiquitylation by cullinRING ligases. It prevents the discharge of Ubiquitin to acceptor lysines on the target proteins. In 
particular, this molecule leads to an accumulation of the CDK inhibitor p2 $7^{\text {kip } 1}$, a target of the SCF complex, which contributes to decreased cancer cell lines proliferation [163, 164]. Using a virtual screening, the triazine analog SMI\#9 was identified as an inhibitor of the Ubiquitin E2 Rad6B via binding to its catalytic site [165]. This molecule was shown to enhance cancer cell sensitivity to platinum-based drugs, including in vivo [166].

Small molecules targeting the SUMO E2 Ubc9 have also been identified in various screens. Spectomycin B1, which was originally identified as an antibiotic, directly binds to Ubc9 and prevents to formation of the Ubc9-SUMO thioester bond. It inhibits ER $\alpha$-regulated gene expression and growth of ER $\alpha$-positive breast-cancer cell lines [167, 168]. The flavonoid derivative 2-D08 was found to inhibit the transfer of SUMO from Ubc9 to target proteins [169]. Moreover, 2-D08 also sensitized non-promyelocytic AML cells to retinoids-induced differentiation and death both in vitro and in vivo [170]. Unfortunately, all of these SUMO E2 inhibitors have low potency and poor solubility, which prevents their use in therapy.

\section{E3 inhibitors}

Inhibiting E1 or E2 enzymes affects the activity of the whole UbL pathway, which may entail deleterious effects on normal, non-cancerous cells. Targeting E3s is consequently considered as a more specific and, potentially, less toxic approach in living individuals. To date, no molecule targeting SUMO or Nedd8 E3s has been identified. By contrast, many molecules targeting Ubiquitin E3s have been discovered [171], as illustrated below in the case of MDM2 and IAPs.

- MDM2 inhibitors

As mentioned previously, MDM2 is physiologically responsible for the Ubiquitylation of the tumor suppressor p53, but is overexpressed in numerous cancers, preventing p53 pathway activation, in particular in case of genotoxic insults. Inhibiting MDM2 pharmacologically therefore constitutes an intense research area with several molecules in preclinical development and others already in clinical trials [172]. Nutlins are imidazoline compounds, which compete with p53 for the binding to MDM2. Such a competition restores the p53 pathway via inhibiting p53 degradation and induces cell cycle arrest and apoptosis of cancer cell lines both in vitro and in vivo [173]. RG7112, a member of the Nutlin family, was the first MDM2 inhibitor to be used in phase I clinical trials, in particular for liposarcoma- [174] and hematological malignanciespresenting patients [175]. This compound was shown to efficiently activate p53 in these tumors and a fraction of patients showed a clinical response. However, therapy-related adverse events 
were observed in most of treated individuals. Quite similarly to Nutlins, MI-219 mimicks p53 primary structure motifs, binds to MDM2 and prevents its association with p53. It permits robust inhibition of tumor growth in vivo without affecting normal tissues in mouse cancer models [176]. AMG-232 is also to be added to the list of small molecules inhibiting the p53-MDM2 interaction [177]. This molecule, which can be administered orally and is highly potent, is currently tested in phase I and II clinical trials [178]. Another emerging approach to target the p53/MDM2 interaction is the use of stapled peptides. These peptides mimick $\alpha$-helixes through side-chain crosslinking between non-natural amino acids introduced in the peptide during synthesis [179]. ALRN-6924 is a stapled peptide that efficiently disrupts the p53/MDM2 interaction, activates p53-dependent transcriptional programs and shows a robust antileukemic activity in mouse preclinical models [180]. Phase I/II trials are ongoing in patients with solid tumors and hematological malignancies (clinicaltrial.gov identifier: NCT02264613, NCT02909972).

- IAP inhibitors

As presented above, IAP/BIRC family members are Ubiquitin E3 ligases, which inhibit apoptosis by preventing, directly or indirectly, the activation of Caspase-3 and -9. SMAC is a mitochondrial antagonist of IAPs binding to their BIR domain and, thereby, preventing their activation. SMACmimetics mimicking the N-terminal residues of SMAC induce the dimerization of IAPs, which is followed by auto-Ubiquitylation and subsequent degradation [181]. These molecules were shown to have anti-tumoral activity as single agents or when combined with cytotoxic agents in various preclinical models. For example, Birinapan is a bivalent SMAC mimetic that was shown to activate RIPK-1-dependent apoptosis in relapsed and refractory Acute Lymphoblastic Leukemias (ALL) and to efficiently limit tumor growth in vivo [182]. It was also shown to synergize with various drugs, including the DNA-demethylating agent 5-azacytidine in AMLs [183]. A phase I clinical trial showed that it is well tolerated and leads to an important reduction of cIAP1 and the activation of cell-death pathways in the tumors and PBMCs (peripheral blood mononuclear cells) from the treated patients [184]. Similar results were obtained with LCL161, another SMAC mimetic under clinical development [185].

\section{Conclusion}

In conclusion, SUMO, Nedd8 and Ubiquitin play key roles in the control of essential cellular pathways and functions that are often dysregulated in cancer and/or participate to cancer response to therapies. Moreover, enzymes of SUMO, Nedd8 and Ubiquitin pathways are also dysregulated 
in many tumor types. They therefore constitute attractive therapeutic targets. Intense efforts by academic and industry laboratories have recently been made to discover small pharmacological agents targeting them. A number of these are now being tested in early phase clinical trials and others are about to enter clinical testing. This might pave the way to better cancer treatment.

\section{Acknowledgements}

We are grateful to all members of the "Oncogenesis and Immunotherapy" group of IGMM for support and fruitful discussions. Funding was provided by the CNRS, Ligue Nationale contre le Cancer (Programme Equipe Labellisée), INCA (ROSAML), Association Laurette Fugain (contract ALF-2017/02), the Fondation ARC (to PG), the Fédération Leucémie Espoir, The EpiGenMed Labex and the ANR under the "Investissements d'avenir" programme (ANR-16IDEX-0006).

\section{References}

1. van der Veen AG, Ploegh HL (2012) Ubiquitin-Like Proteins. Annu Rev Biochem 81:323357. https://doi.org/10.1146/annurev-biochem-093010-153308

2. Vijay-Kumar S, Bugg CE, Cook WJ (1987) Structure of ubiquitin refined at 1.8 A resolution. J Mol Biol 194:531-544

3. Kerscher O, Felberbaum R, Hochstrasser M (2006) Modification of Proteins by Ubiquitin and Ubiquitin-Like Proteins. Annu Rev Cell Dev Biol 22:159-180. https://doi.org/10.1146/annurev.cellbio.22.010605.093503

4. Cappadocia L, Lima CD (2018) Ubiquitin-like Protein Conjugation: Structures, Chemistry, and Mechanism. Chem Rev 118:889-918. https://doi.org/10.1021/acs.chemrev.6b00737

5. Zheng N, Shabek N (2017) Ubiquitin Ligases: Structure, Function, and Regulation. Annu Rev Biochem 86:129-157. https://doi.org/10.1146/annurev-biochem-060815-014922

6. Pichler A, Fatouros C, Lee H, Eisenhardt N (2017) SUMO conjugation - a mechanistic view. Biomol Concepts 8:13-36. https://doi.org/10.1515/bmc-2016-0030

7. Komander D, Rape M (2012) The Ubiquitin Code. Annu Rev Biochem 81:203-229. https://doi.org/10.1146/annurev-biochem-060310-170328

8. Yau R, Rape M (2016) The increasing complexity of the ubiquitin code. Nat Cell Biol 18:579-586. https://doi.org/10.1038/ncb3358

9. Clague MJ, Urbé S, Komander D (2019) Breaking the chains: deubiquitylating enzyme specificity begets function. Nat Rev Mol Cell Biol. https://doi.org/10.1038/s41580-0190099-1 
10. Kunz K, Piller T, Müller S (2018) SUMO-specific proteases and isopeptidases of the SENP family at a glance. J Cell Sci 131:jcs211904. https://doi.org/10.1242/jcs.211904

11. Gong L, Yeh ETH (2006) Characterization of a Family of Nucleolar SUMO-specific Proteases with Preference for SUMO-2 or SUMO-3. J Biol Chem 281:15869-15877. https://doi.org/10.1074/jbc.M511658200

12. Schulz S, Chachami G, Kozaczkiewicz L, et al (2012) Ubiquitin-specific protease-like 1 (USPL1) is a SUMO isopeptidase with essential, non-catalytic functions. EMBO Rep 13:930-938. https://doi.org/10.1038/embor.2012.125

13. Flotho A, Melchior F (2013) Sumoylation: A Regulatory Protein Modification in Health and Disease. Annu Rev Biochem 82:357-385. https://doi.org/10.1146/annurev-biochem061909-093311

14. Kwon YT, Ciechanover A (2017) The Ubiquitin Code in the Ubiquitin-Proteasome System and Autophagy. Trends Biochem Sci 42:873-886. https://doi.org/10.1016/j.tibs.2017.09.002

15. Enchev RI, Schulman BA, Peter M (2015) Protein neddylation: beyond cullin-RING ligases. Nat Rev Mol Cell Biol 16:30-44. https://doi.org/10.1038/nrm3919

16. Chau V, Tobias JW, Bachmair A, et al (1989) A multiubiquitin chain is confined to specific lysine in a targeted short-lived protein. Science 243:1576-1583

17. Glickman MH, Ciechanover A (2002) The ubiquitin-proteasome proteolytic pathway: destruction for the sake of construction. Physiol Rev 82:373-428. https://doi.org/10.1152/physrev.00027.2001

18. Ciechanover A (2017) Intracellular protein degradation: From a vague idea thru the lysosome and the ubiquitin-proteasome system and onto human diseases and drug targeting. Best Pract Res Clin Haematol 30:341-355. https://doi.org/10.1016/j.beha.2017.09.001

19. Flick K, Raasi S, Zhang $\mathrm{H}$, et al (2006) A ubiquitin-interacting motif protects polyubiquitinated Met4 from degradation by the 26S proteasome. Nat Cell Biol 8:509-515. https://doi.org/10.1038/ncb1402

20. Le Cam L, Linares LK, Paul C, et al (2006) E4F1 is an atypical ubiquitin ligase that modulates p53 effector functions independently of degradation. Cell 127:775-788. https://doi.org/10.1016/j.cell.2006.09.031

21. Yao T, Ndoja A (2012) Regulation of gene expression by the ubiquitin-proteasome system. Semin Cell Dev Biol 23:523-529. https://doi.org/10.1016/j.semcdb.2012.02.006

22. Lee BL, Singh A, Mark Glover JN, et al (2017) Molecular Basis for K63-Linked Ubiquitination Processes in Double-Strand DNA Break Repair: A Focus on Kinetics and Dynamics. J Mol Biol 429:3409-3429. https://doi.org/10.1016/j.jmb.2017.05.029 
23. Wu X, Karin M (2015) Emerging roles of Lys63-linked polyubiquitylation in immune responses. Immunol Rev 266:161-174. https://doi.org/10.1111/imr.12310

24. Schmukle AC, Walczak H (2012) No one can whistle a symphony alone - how different

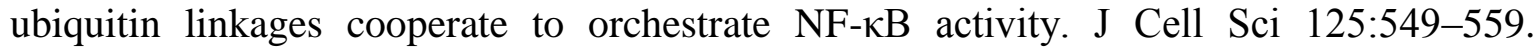
https://doi.org/10.1242/jcs.091793

25. Wickliffe KE, Williamson A, Meyer H-J, et al (2011) K11-linked ubiquitin chains as novel regulators of cell division. Trends Cell Biol 21:656-663. https://doi.org/10.1016/j.tcb.2011.08.008

26. Kirisako T, Kamei K, Murata S, et al (2006) A ubiquitin ligase complex assembles linear polyubiquitin chains. EMBO J 25:4877-4887. https://doi.org/10.1038/sj.emboj.7601360

27. Rittinger K, Ikeda F (2017) Linear ubiquitin chains: enzymes, mechanisms and biology. Open Biol 7:. https://doi.org/10.1098/rsob.170026

28. Spit M, Rieser E, Walczak H (2019) Linear ubiquitination at a glance. J Cell Sci 132:jcs208512. https://doi.org/10.1242/jcs.208512

29. Haglund K, Sigismund S, Polo S, et al (2003) Multiple monoubiquitination of RTKs is sufficient for their endocytosis and degradation. Nat Cell Biol 5:461-466. https://doi.org/10.1038/ncb983

30. Haglund K, Di Fiore PP, Dikic I (2003) Distinct monoubiquitin signals in receptor endocytosis. Trends Biochem Sci 28:598-604. https://doi.org/10.1016/j.tibs.2003.09.005

31. Sadowski M, Suryadinata R, Tan AR, et al (2012) Protein monoubiquitination and polyubiquitination generate structural diversity to control distinct biological processes. IUBMB Life 64:136-142. https://doi.org/10.1002/iub.589

32. Hendriks IA, Vertegaal ACO (2016) A comprehensive compilation of SUMO proteomics. Nat Rev Mol Cell Biol 17:581-595. https://doi.org/10.1038/nrm.2016.81

33. Hendriks IA, Lyon D, Young C, et al (2017) Site-specific mapping of the human SUMO proteome reveals co-modification with phosphorylation. Nat Struct Mol Biol 24:325-336. https://doi.org/10.1038/nsmb.3366

34. Tatham MH, Geoffroy M-C, Shen L, et al (2008) RNF4 is a poly-SUMO-specific E3 ubiquitin ligase required for arsenic-induced PML degradation. Nat Cell Biol 10:538-546. https://doi.org/10.1038/ncb1716

35. Lallemand-Breitenbach V, Jeanne M, Benhenda S, et al (2008) Arsenic degrades PML or PML-RAR $\alpha$ through a SUMO-triggered RNF4/ubiquitin-mediated pathway. Nat Cell Biol 10:547-555. https://doi.org/10.1038/ncb1717

36. Sun H, Hunter T (2012) PolySUMO-binding proteins identified through a string search. J Biol Chem. https://doi.org/10.1074/jbc.M112.410985 
37. Armstrong AA, Mohideen F, Lima CD (2012) Recognition of SUMO-modified PCNA requires tandem receptor motifs in Srs2. Nature 483:59-63. https://doi.org/10.1038/nature10883

38. Garvin AJ, Morris JR (2017) SUMO, a small, but powerful, regulator of double-strand break repair. Philos Trans R Soc B Biol Sci 372:. https://doi.org/10.1098/rstb.2016.0281

39. Neyret-Kahn H, Benhamed M, Ye T, et al (2013) Sumoylation at chromatin governs coordinated repression of a transcriptional program essential for cell growth and proliferation. Genome Res 23:1563-79. https://doi.org/10.1101/gr.154872.113

40. Cossec J-C, Theurillat I, Chica C, et al (2018) SUMO Safeguards Somatic and Pluripotent Cell Identities by Enforcing Distinct Chromatin States. Cell Stem Cell 23:742-757.e8. https://doi.org/10.1016/j.stem.2018.10.001

41. Rosonina E, Akhter A, Dou Y, et al (2017) Regulation of transcription factors by sumoylation. Transcription 8:220-231. https://doi.org/10.1080/21541264.2017.1311829

42. Tempé D, Vives E, Brockly F, et al (2014) SUMOylation of the inducible (c-Fos:cJun)/AP-1 transcription complex occurs on target promoters to limit transcriptional activation. Oncogene 33:921-927. https://doi.org/10.1038/onc.2013.4

43. Chymkowitch P, P AN, Aanes H, et al (2015) Sumoylation of Rap1 mediates the recruitment of TFIID to promote transcription of ribosomal protein genes. Genome Res 25:897-906. https://doi.org/10.1101/gr.185793.114

44. Psakhye I, Jentsch S (2012) Protein Group Modification and Synergy in the SUMO Pathway as Exemplified in DNA Repair. Cell 151:807-20. https://doi.org/10.1016/j.cell.2012.10.021

45. Tempé D, Piechaczyk M, Bossis G (2008) SUMO under stress. Biochem Soc Trans 36:874-878. https://doi.org/10.1042/BST0360874

46. Seifert A, Schofield P, Barton GJ, Hay RT (2015) Proteotoxic stress reprograms the chromatin landscape of SUMO modification. Sci Signal 8:rs7-rs7. https://doi.org/10.1126/scisignal.aaa2213

47. Liebelt F, Sebastian RM, Moore CL, et al (2019) SUMOylation and the HSF1-Regulated Chaperone Network Converge to Promote Proteostasis in Response to Heat Shock. Cell Rep 26:236-249.e4. https://doi.org/10.1016/j.celrep.2018.12.027

48. Bossis G, Melchior F (2006) Regulation of SUMOylation by Reversible Oxidation of SUMO Conjugating Enzymes. Mol Cell 21:349-357. https://doi.org/10.1016/j.molcel.2005.12.019

49. Stankovic- Valentin N, Drzewicka K, König C, et al (2016) Redox regulation of SUMO enzymes is required for ATM activity and survival in oxidative stress. EMBO J 35:13121329. https://doi.org/10.15252/embj.201593404 
50. Stankovic-Valentin N, Melchior F (2018) Control of SUMO and Ubiquitin by ROS: Signaling and disease implications. Mol Aspects Med 63:3-17. https://doi.org/10.1016/j.mam.2018.07.002

51. Deshaies RJ, Emberley ED, Saha A (2010) Control of cullin-ring ubiquitin ligase activity by nedd8. Subcell Biochem 54:41-56. https://doi.org/10.1007/978-1-4419-6676-6_4

52. Xirodimas DP, Saville MK, Bourdon J-C, et al (2004) Mdm2-mediated NEDD8 conjugation of p53 inhibits its transcriptional activity. Cell 118:83-97. https://doi.org/10.1016/j.cell.2004.06.016

53. Watson IR, Blanch A, Lin DCC, et al (2006) Mdm2-mediated NEDD8 modification of TAp73 regulates its transactivation function. J Biol Chem 281:34096-34103. https://doi.org/10.1074/jbc.M603654200

54. Loftus SJ, Liu G, Carr SM, et al (2012) NEDDylation regulates E2F-1-dependent transcription. EMBO Rep 13:811-818. https://doi.org/10.1038/embor.2012.113

55. Aoki I, Higuchi M, Gotoh Y (2013) NEDDylation controls the target specificity of E2F1 and apoptosis induction. Oncogene 32:3954-3964. https://doi.org/10.1038/onc.2012.428

56. Russell RC, Ohh M (2008) NEDD8 acts as a "molecular switch" defining the functional selectivity of VHL. EMBO Rep 9:486-491. https://doi.org/10.1038/embor.2008.19

57. Gao F, Cheng J, Shi T, Yeh ETH (2006) Neddylation of a breast cancer-associated protein recruits a class III histone deacetylase that represses NFKB-dependent transcription. Nat Cell Biol 8:1171-1177. https://doi.org/10.1038/ncb1483

58. Renaudin X, Guervilly J-H, Aoufouchi S, Rosselli F (2014) Proteomic analysis reveals a FANCA-modulated neddylation pathway involved in CXCR5 membrane targeting and cell mobility. J Cell Sci 127:3546-3554. https://doi.org/10.1242/jcs.150706

59. Sundqvist A, Liu G, Mirsaliotis A, Xirodimas DP (2009) Regulation of nucleolar signalling to p53 through NEDDylation of L11. EMBO Rep 10:1132-1139. https://doi.org/10.1038/embor.2009.178

60. Mahata B, Sundqvist A, Xirodimas DP (2012) Recruitment of RPL11 at promoter sites of p53-regulated genes upon nucleolar stress through NEDD8 and in an Mdm2-dependent manner. Oncogene 31:3060-3071. https://doi.org/10.1038/onc.2011.482

61. Zhang J, Bai D, Ma X, et al (2014) hCINAP is a novel regulator of ribosomal proteinHDM2-p53 pathway by controlling NEDDylation of ribosomal protein S14. Oncogene 33:246-254. https://doi.org/10.1038/onc.2012.560

62. El Motiam A, Vidal S, de la Cruz-Herrera CF, et al (2019) Interplay between SUMOylation and NEDDylation regulates RPL11 localization and function. FASEB J Off Publ Fed Am Soc Exp Biol 33:643-651. https://doi.org/10.1096/fj.201800341RR 
63. Maghames CM, Lobato-Gil S, Perrin A, et al (2018) NEDDylation promotes nuclear protein aggregation and protects the Ubiquitin Proteasome System upon proteotoxic stress. Nat Commun 9:4376. https://doi.org/10.1038/s41467-018-06365-0

64. Hanahan D, Weinberg RA (2011) Hallmarks of Cancer: The Next Generation. Cell 144:646-674. https://doi.org/10.1016/j.cell.2011.02.013

65. Seeler J-S, Dejean A (2017) SUMO and the robustness of cancer. Nat Rev Cancer 17:184197. https://doi.org/10.1038/nrc.2016.143

66. Zhou L, Zhang W, Sun Y, Jia L (2018) Protein neddylation and its alterations in human cancers for targeted therapy. Cell Signal 44:92-102. https://doi.org/10.1016/j.cellsig.2018.01.009

67. Niazi S, Purohit M, Niazi JH (2018) Role of p53 circuitry in tumorigenesis: A brief review. Eur J Med Chem 158:7-24. https://doi.org/10.1016/j.ejmech.2018.08.099

68. Sane S, Rezvani K (2017) Essential Roles of E3 Ubiquitin Ligases in p53 Regulation. Int J Mol Sci 18:. https://doi.org/10.3390/ijms18020442

69. Honda R, Tanaka H, Yasuda H (1997) Oncoprotein MDM2 is a ubiquitin ligase E3 for tumor suppressor p53. FEBS Lett 420:25-27. https://doi.org/10.1016/S00145793(97)01480-4

70. Kubbutat MH, Jones SN, Vousden KH (1997) Regulation of p53 stability by Mdm2. Nature 387:299-303. https://doi.org/10.1038/387299a0

71. Carr MI, Jones SN (2016) Regulation of the Mdm2-p53 signaling axis in the DNA damage response and tumorigenesis. Transl Cancer Res 5:707-724. https://doi.org/10.21037/tcr.2016.11.75

72. Scheffner M, Werness BA, Huibregtse JM, et al (1990) The E6 oncoprotein encoded by human papillomavirus types 16 and 18 promotes the degradation of p53. Cell 63:11291136

73. Martinez-Zapien D, Ruiz FX, Poirson J, et al (2016) Structure of the E6/E6AP/p53 complex required for HPV-mediated degradation of p53. Nature 529:541-545. https://doi.org/10.1038/nature16481

74. Li M, Brooks CL, Wu-Baer F, et al (2003) Mono- Versus Polyubiquitination: Differential Control of p53 Fate by Mdm2. Science 302:1972-1975. https://doi.org/10.1126/science.1091362

75. Lee JT, Gu W (2010) The multiple levels of regulation by p53 ubiquitination. Cell Death Differ 17:86-92. https://doi.org/10.1038/cdd.2009.77

76. Kruse J-P, Gu W (2009) MSL2 Promotes Mdm2-independent Cytoplasmic Localization of p53. J Biol Chem 284:3250-3263. https://doi.org/10.1074/jbc.M805658200 
77. Laine A, Ronai Z (2007) Regulation of p53 localization and transcription by the HECT domain E3 ligase WWP1. Oncogene 26:1477-1483. https://doi.org/10.1038/sj.onc.1209924

78. Abida WM, Nikolaev A, Zhao W, et al (2007) FBXO11 promotes the Neddylation of p53 and inhibits its transcriptional activity. J Biol Chem 282:1797-1804. https://doi.org/10.1074/jbc.M609001200

79. Liu G, Xirodimas DP (2010) NUB1 promotes cytoplasmic localization of p53 through cooperation of the NEDD8 and ubiquitin pathways. Oncogene 29:2252-2261. https://doi.org/10.1038/onc.2009.494

80. Batuello CN, Hauck PM, Gendron JM, et al (2015) Src phosphorylation converts Mdm2 from a ubiquitinating to a neddylating E3 ligase. Proc Natl Acad Sci U S A 112:17491754. https://doi.org/10.1073/pnas.1416656112

81. Rodriguez MS, Desterro JMP, Lain S, et al (1999) SUMO- 1 modification activates the transcriptional response of p53. EMBO J 18:6455-6461. https://doi.org/10.1093/emboj/18.22.6455

82. Gostissa M, Hengstermann A, Fogal V, et al (1999) Activation of p53 by conjugation to the ubiquitin- like protein SUMO- 1. EMBO J 18:6462-6471. https://doi.org/10.1093/emboj/18.22.6462

83. Muller S, Berger M, Lehembre F, et al (2000) c-Jun and p53 activity is modulated by SUMO-1 modification. J Biol Chem 275:13321-13329

84. Stehmeier P, Muller S (2009) Regulation of p53 family members by the ubiquitin-like SUMO system. DNA Repair 8:491-498. https://doi.org/10.1016/j.dnarep.2009.01.002

85. Kwek SS, Derry J, Tyner AL, et al (2001) Functional analysis and intracellular localization of p53 modified by SUMO-1. Oncogene 20:2587-2599. https://doi.org/10.1038/sj.onc. 1204362

86. Liu X-M, Yang F-F, Yuan Y-F, et al (2013) SUMOylation of Mouse p53b by SUMO-1 Promotes Its Pro-Apoptotic Function in Ovarian Granulosa Cells. PLOS ONE 8:e63680. https://doi.org/10.1371/journal.pone.0063680

87. Ashikari D, Takayama K, Tanaka T, et al (2017) Androgen induces G3BP2 and SUMOmediated p53 nuclear export in prostate cancer. Oncogene 36:6272-6281. https://doi.org/10.1038/onc.2017.225

88. Imbert V, Peyron J-F (2017) NF- $\mathrm{KB}$ in Hematological Malignancies. Biomedicines 5:. https://doi.org/10.3390/biomedicines5020027

89. Seo J, Kim MW, Bae K-H, et al (2019) The roles of ubiquitination in extrinsic cell death pathways and its implications for therapeutics. Biochem Pharmacol 162:21-40. https://doi.org/10.1016/j.bcp.2018.11.012 
90. Desterro JMP, Rodriguez MS, Hay RT (1998) SUMO-1 Modification of IкB $\alpha$ Inhibits NF$\kappa B$ Activation. Mol Cell 2:233-239. https://doi.org/10.1016/S1097-2765(00)80133-1

91. Huang TT, Wuerzberger-Davis SM, Wu Z-H, Miyamoto S (2003) Sequential modification of NEMO/IKKgamma by SUMO-1 and ubiquitin mediates NF-kappaB activation by genotoxic stress. Cell 115:565-576

92. Noguchi K, Okumura F, Takahashi N, et al (2011) TRIM40 promotes neddylation of IKK $\gamma$ and is downregulated in gastrointestinal cancers. Carcinogenesis 32:995-1004. https://doi.org/10.1093/carcin/bgr068

93. Colak S, ten Dijke P (2017) Targeting TGF- $\beta$ Signaling in Cancer. Trends Cancer 3:56-71. https://doi.org/10.1016/j.trecan.2016.11.008

94. Budi EH, Duan D, Derynck R (2017) Transforming Growth Factor- $\beta$ Receptors and Smads: Regulatory Complexity and Functional Versatility. Trends Cell Biol 27:658-672. https://doi.org/10.1016/j.tcb.2017.04.005

95. Iyengar PV (2017) Regulation of Ubiquitin Enzymes in the TGF- $\beta$ Pathway. Int J Mol Sci 18:877. https://doi.org/10.3390/ijms18040877

96. Kavsak P, Rasmussen RK, Causing CG, et al (2000) Smad7 Binds to Smurf2 to Form an E3 Ubiquitin Ligase that Targets the TGF $\beta$ Receptor for Degradation. Mol Cell 6:13651375. https://doi.org/10.1016/S1097-2765(00)00134-9

97. Ebisawa T, Fukuchi M, Murakami G, et al (2001) Smurf1 interacts with transforming growth factor-beta type I receptor through $\mathrm{Smad} 7$ and induces receptor degradation. J Biol Chem 276:12477-12480. https://doi.org/10.1074/jbc.C100008200

98. Eichhorn PJA, Rodón L, Gonzàlez-Juncà A, et al (2012) USP15 stabilizes TGF- $\beta$ receptor I and promotes oncogenesis through the activation of TGF- $\beta$ signaling in glioblastoma. Nat Med 18:429-435. https://doi.org/10.1038/nm.2619

99. Xie P, Zhang M, He S, et al (2014) The covalent modifier Nedd8 is critical for the activation of Smurf1 ubiquitin ligase in tumorigenesis. Nat Commun 5:3733. https://doi.org/10.1038/ncomms4733

100. He S, Cao Y, Xie P, et al (2017) The Nedd8 Non-covalent Binding Region in the Smurf HECT Domain is Critical to its Ubiquitn Ligase Function. Sci Rep 7:. https://doi.org/10.1038/srep41364

101. Chanda A, Sarkar A, Bonni S (2018) The SUMO System and TGF $\beta$ Signaling Interplay in Regulation of Epithelial-Mesenchymal Transition: Implications for Cancer Progression. Cancers 10:. https://doi.org/10.3390/cancers 10080264

102. Kang JS, Saunier EF, Akhurst RJ, Derynck R (2008) The type I TGF- $\beta$ receptor is covalently modified and regulated by sumoylation. Nat Cell Biol 10:654-664. https://doi.org/10.1038/ncb1728 
103. Tan M, Zhang D, Zhang E, et al (2017) SENP2 suppresses epithelial-mesenchymal transition of bladder cancer cells through deSUMOylation of TGF- $\beta$ RI. Mol Carcinog 56:2332-2341. https://doi.org/10.1002/mc.22687

104. Chandhoke AS, Karve K, Dadakhujaev S, et al (2016) The ubiquitin ligase Smurf2 suppresses TGF $\beta$-induced epithelial-mesenchymal transition in a sumoylation-regulated manner. Cell Death Differ 23:876-888. https://doi.org/10.1038/cdd.2015.152

105. Chandhoke AS, Chanda A, Karve K, et al (2017) The PIAS3-Smurf2 sumoylation pathway suppresses breast cancer organoid invasiveness. Oncotarget 8:21001-21014. https://doi.org/10.18632/oncotarget.15471

106. Ikeuchi Y, Dadakhujaev S, Chandhoke AS, et al (2014) TIF1 $\gamma$ Protein Regulates Epithelial-Mesenchymal Transition by Operating as a Small Ubiquitin-like Modifier (SUMO) E3 Ligase for the Transcriptional Regulator SnoN1. J Biol Chem 289:2506725078. https://doi.org/10.1074/jbc.M114.575878

107. Long J, Zuo D, Park M (2005) Pc2-mediated Sumoylation of Smad-interacting Protein 1 Attenuates Transcriptional Repression of E-cadherin. J Biol Chem 280:35477-35489. https://doi.org/10.1074/jbc.M504477200

108. Gudey SK, Sundar R, Heldin C-H, et al (2017) Pro-invasive properties of Snail1 are regulated by sumoylation in response to TGF $\beta$ stimulation in cancer. Oncotarget 8:9770397726. https://doi.org/10.18632/oncotarget.20097

109. Xie Y, Liu S, Lu W, et al (2014) Slug regulates E- cadherin repression via p19Arf in prostate tumorigenesis. Mol Oncol 8:1355-1364. https://doi.org/10.1016/j.molonc.2014.05.006

110. Sun H, Liu Y, Hunter T (2014) Multiple Arkadia/RNF111 Structures Coordinate Its Polycomb Body Association and Transcriptional Control. Mol Cell Biol 34:2981-2995. https://doi.org/10.1128/MCB.00036-14

111. Müller S, Matunis MJ, Dejean A (1998) Conjugation with the ubiquitin- related modifier SUMO- 1 regulates the partitioning of PML within the nucleus. EMBO J 17:61-70. https://doi.org/10.1093/emboj/17.1.61

112. Kamitani T, Nguyen HP, Kito K, et al (1998) Covalent Modification of PML by the Sentrin Family of Ubiquitin-like Proteins. J Biol Chem 273:3117-3120. https://doi.org/10.1074/jbc.273.6.3117

113. Duprez E, Saurin AJ, Desterro JM, et al (1999) SUMO-1 modification of the acute promyelocytic leukaemia protein PML: implications for nuclear localisation. J Cell Sci 112:381-393

114. Sahin U, Ferhi O, Jeanne M, et al (2014) Oxidative stress-induced assembly of PML nuclear bodies controls sumoylation of partner proteins. J Cell Biol 204:931-945. https://doi.org/10.1083/jcb.201305148 
115. Weis K, Rambaud S, Lavau C, et al (1994) Retinoic acid regulates aberrant nuclear localization of PML-RAR alpha in acute promyelocytic leukemia cells. Cell 76:345-356

116. de Thé H (2018) Differentiation therapy revisited. Nat Rev Cancer 18:117-127. https://doi.org/10.1038/nrc.2017.103

117. Ablain J, Rice K, Soilihi H, et al (2014) Activation of a promyelocytic leukemia-tumor protein 53 axis underlies acute promyelocytic leukemia cure. Nat Med 20:167-174. https://doi.org/10.1038/nm.3441

118. Mohamed MS, Bishr MK, Almutairi FM, Ali AG (2017) Inhibitors of apoptosis: clinical implications in cancer. Apoptosis 22:1487-1509. https://doi.org/10.1007/s10495-017$1429-4$

119. Huang X, Wang X, Yuan X, et al (2019) XIAP facilitates breast and colon carcinoma growth via promotion of p62 depletion through ubiquitination-dependent proteasomal degradation. Oncogene 38:1448. https://doi.org/10.1038/s41388-018-0513-8

120. Engel K, Rudelius M, Slawska J, et al (2016) USP9X stabilizes XIAP to regulate mitotic cell death and chemoresistance in aggressive B- cell lymphoma. EMBO Mol Med 8:851862. https://doi.org/10.15252/emmm.201506047

121. Zheng N, Zhou Q, Wang Z, Wei W (2016) Recent advances in SCF ubiquitin ligase complex: clinical implications. Biochim Biophys Acta 1866:12-22. https://doi.org/10.1016/j.bbcan.2016.05.001

122. Uddin S, Bhat AA, Krishnankutty R, et al (2016) Involvement of F-BOX proteins in progression and development of human malignancies. Semin Cancer Biol 36:18-32. https://doi.org/10.1016/j.semcancer.2015.09.008

123. Shimizu K, Nihira NT, Inuzuka H, Wei W (2018) Physiological functions of FBW7 in cancer and metabolism. Cell Signal 46:15-22. https://doi.org/10.1016/j.cellsig.2018.02.009

124. Asnafi V, Buzyn A, Noir SL, et al (2009) NOTCH1/FBXW7 mutation identifies a large subgroup with favorable outcome in adult T-cell acute lymphoblastic leukemia (T-ALL): a Group for Research on Adult Acute Lymphoblastic Leukemia (GRAALL) study. Blood 113:3918-3924. https://doi.org/10.1182/blood-2008-10-184069

125. Hao Z, Huang S (2015) E3 ubiquitin ligase Skp2 as an attractive target in cancer therapy. Front Biosci Landmark Ed 20:474-490

126. Masuda T, Inoue H, Sonoda H, et al (2002) Clinical and Biological Significance of SPhase Kinase-associated Protein 2 (Skp2) Gene Expression in Gastric Carcinoma: Modulation of Malignant Phenotype by Skp2 Overexpression, Possibly via p27 Proteolysis. Cancer Res 62:3819-3825 
127. Ougolkov A, Zhang B, Yamashita K, et al (2004) Associations Among $\beta$-TrCP, an E3 Ubiquitin Ligase Receptor, $\beta$-Catenin, and NF- $\mathrm{KB}$ in Colorectal Cancer. JNCI J Natl Cancer Inst 96:1161-1170. https://doi.org/10.1093/jnci/djh219

128. Li L, Wang M, Yu G, et al (2014) Overactivated Neddylation Pathway as a Therapeutic Target in Lung Cancer. JNCI J Natl Cancer Inst 106:. https://doi.org/10.1093/jnci/dju083

129. Gao Q, Yu G-Y, Shi J-Y, et al (2014) Neddylation pathway is up-regulated in human intrahepatic cholangiocarcinoma and serves as a potential therapeutic target. Oncotarget 5:7820-7832. https://doi.org/10.18632/oncotarget.2309

130. Guo Z, Wang Y, Zhao Y, et al (2019) The pivotal oncogenic role of Jab1/CSN5 and its therapeutic implications in human cancer. Gene 687:219-227. https://doi.org/10.1016/j.gene.2018.11.061

131. He P, Sun X, Cheng H-J, et al (2018) UBA2 promotes proliferation of colorectal cancer. Mol Med Rep 18:5552-5562. https://doi.org/10.3892/mmr.2018.9613

132. Fang S, Qiu J, Wu Z, et al (2017) Down-regulation of UBC9 increases the sensitivity of hepatocellular carcinoma to doxorubicin. Oncotarget 8:49783-49795. https://doi.org/10.18632/oncotarget.17939

133. Hoellein A, Fallahi M, Schoeffmann S, et al (2014) Myc-induced SUMOylation is a therapeutic vulnerability for B-cell lymphoma. Blood 124:2081-2090. https://doi.org/10.1182/blood-2014-06-584524

134. Kessler JD, Kahle KT, Sun T, et al (2011) A SUMOylation-Dependent Transcriptional Subprogram Is Required for Myc-Driven Tumorigenesis. Science 335:348-53. https://doi.org/10.1126/science. 1212728

135. Wang Q, Xia N, Li T, et al (2013) SUMO-specific protease 1 promotes prostate cancer progression and metastasis. Oncogene 32:2493-2498. https://doi.org/10.1038/onc.2012.250

136. Liu F, Li L, Li Y, et al (2018) Overexpression of SENP1 reduces the stemness capacity of osteosarcoma stem cells and increases their sensitivity to HSVtk/GCV. Int J Oncol 53:2010-2020. https://doi.org/10.3892/ijo.2018.4537

137. Huang X, Dixit VM (2016) Drugging the undruggables: exploring the ubiquitin system for drug development. Cell Res 26:484-498. https://doi.org/10.1038/cr.2016.31

138. Farshi P, Deshmukh RR, Nwankwo JO, et al (2015) Deubiquitinases (DUBs) and DUB inhibitors: a patent review. Expert Opin Ther Pat 25:1191-1208. https://doi.org/10.1517/13543776.2015.1056737

139. D'Arcy P, Wang X, Linder S (2015) Deubiquitinase inhibition as a cancer therapeutic strategy. Pharmacol Ther 147:32-54. https://doi.org/10.1016/j.pharmthera.2014.11.002 
140. Xu GW, Ali M, Wood TE, et al (2010) The ubiquitin-activating enzyme E1 as a therapeutic target for the treatment of leukemia and multiple myeloma. Blood 115:22512259. https://doi.org/10.1182/blood-2009-07-231191

141. Yang Y, Kitagaki J, Dai R-M, et al (2007) Inhibitors of Ubiquitin-Activating Enzyme (E1), a New Class of Potential Cancer Therapeutics. Cancer Res 67:9472-9481. https://doi.org/10.1158/0008-5472.CAN-07-0568

142. Hyer ML, Milhollen MA, Ciavarri J, et al (2018) A small-molecule inhibitor of the ubiquitin activating enzyme for cancer treatment. Nat Med 24:186-193. https://doi.org/10.1038/nm.4474

143. Barghout SH, Patel PS, Wang X, et al (2019) Preclinical evaluation of the selective smallmolecule UBA1 inhibitor, TAK-243, in acute myeloid leukemia. Leukemia 33:37. https://doi.org/10.1038/s41375-018-0167-0

144. Brownell JE, Sintchak MD, Gavin JM, et al (2010) Substrate-Assisted Inhibition of Ubiquitin-like Protein-Activating Enzymes: The NEDD8 E1 Inhibitor MLN4924 Forms a NEDD8-AMP Mimetic In Situ. Mol Cell 37:102-111. https://doi.org/10.1016/j.molcel.2009.12.024

145. Soucy TA, Smith PG, Milhollen MA, et al (2009) An inhibitor of NEDD8-activating enzyme as a new approach to treat cancer. Nature 458:732-736. https://doi.org/10.1038/nature07884

146. Sarantopoulos J, Shapiro GI, Cohen RB, et al (2016) Phase I Study of the Investigational NEDD8-Activating Enzyme Inhibitor Pevonedistat (TAK-924/MLN4924) in Patients with Advanced Solid Tumors. Clin Cancer Res Off J Am Assoc Cancer Res 22:847-857. https://doi.org/10.1158/1078-0432.CCR-15-1338

147. Shah JJ, Jakubowiak AJ, O'Connor OA, et al (2016) Phase I Study of the Novel Investigational NEDD8-Activating Enzyme Inhibitor Pevonedistat (MLN4924) in Patients with Relapsed/Refractory Multiple Myeloma or Lymphoma. Clin Cancer Res 22:34-43. https://doi.org/10.1158/1078-0432.CCR-15-1237

148. Bhatia S, Pavlick AC, Boasberg P, et al (2016) A phase I study of the investigational NEDD8-activating enzyme inhibitor pevonedistat (TAK-924/MLN4924) in patients with metastatic melanoma. Invest New Drugs 34:439-449. https://doi.org/10.1007/s10637-016$0348-5$

149. Nawrocki ST, Kelly KR, Smith PG, et al (2015) The NEDD8-Activating Enzyme Inhibitor MLN4924 Disrupts Nucleotide Metabolism and Augments the Efficacy of Cytarabine. Clin Cancer Res 21:439-447. https://doi.org/10.1158/1078-0432.CCR-14-1960

150. Visconte V, Nawrocki ST, Espitia CM, et al (2016) Comprehensive quantitative proteomic profiling of the pharmacodynamic changes induced by MLN4924 in acute myeloid leukemia cells establishes rationale for its combination with azacitidine. Leukemia 30:1190-1194. https://doi.org/10.1038/leu.2015.250 
151. Swords RT, Coutre S, Maris MB, et al (2018) Pevonedistat, a first-in-class NEDD8activating enzyme inhibitor, combined with azacitidine in patients with AML. Blood 131:1415-1424. https://doi.org/10.1182/blood-2017-09-805895

152. Fukuda I, Ito A, Hirai G, et al (2009) Ginkgolic acid inhibits protein SUMOylation by blocking formation of the E1-SUMO intermediate. Chem Biol 16:133-140. https://doi.org/10.1016/j.chembiol.2009.01.009

153. Bossis G, Sarry J-E, Kifagi C, et al (2014) The ROS/SUMO Axis Contributes to the Response of Acute Myeloid Leukemia Cells to Chemotherapeutic Drugs. Cell Rep 7:1815-1823. https://doi.org/10.1016/j.celrep.2014.05.016

154. Bogachek MV, Park JM, De Andrade JP, et al Inhibiting the SUMO Pathway Represses the Cancer Stem Cell Population in Breast and Colorectal Carcinomas. Stem Cell Rep. https://doi.org/10.1016/j.stemcr.2016.11.001

155. Tan J, Chen B, He L, et al (2012) Anacardic acid (6-pentadecylsalicylic acid) induces apoptosis of prostate cancer cells through inhibition of androgen receptor and activation of p53 signaling. Chin J Cancer Res Chung-Kuo Yen Cheng Yen Chiu 24:275-283. https://doi.org/10.3978/j.issn.1000-9604.2012.10.07

156. Baek SH, Ko J-H, Lee JH, et al (2017) Ginkgolic Acid Inhibits Invasion and Migration and TGF- $\beta$-Induced EMT of Lung Cancer Cells Through PI3K/Akt/mTOR Inactivation. J Cell Physiol 232:346-354. https://doi.org/10.1002/jcp.25426

157. Hamdoun S, Efferth T, Hamdoun S, Efferth T (2017) Ginkgolic acids inhibit migration in breast cancer cells by inhibition of NEMO sumoylation and NF-kB activity. Oncotarget 5:. https://doi.org/10.18632/oncotarget.16626

158. Eliseeva ED, Valkov V, Jung M, Jung MO (2007) Characterization of novel inhibitors of histone acetyltransferases. Mol Cancer Ther 6:2391-2398. https://doi.org/10.1158/15357163.MCT-07-0159

159. He X, Riceberg J, Soucy T, et al (2017) Probing the roles of SUMOylation in cancer cell biology by using a selective SAE inhibitor. Nat Chem Biol 13:1164-1171. https://doi.org/10.1038/nchembio.2463

160. Pulvino M, Liang Y, Oleksyn D, et al (2012) Inhibition of proliferation and survival of diffuse large B-cell lymphoma cells by a small-molecule inhibitor of the ubiquitinconjugating enzyme Ubc13-Uev1A. Blood 120:1668-1677. https://doi.org/10.1182/blood2012-02-406074

161. Hodge CD, Edwards RA, Markin CJ, et al (2015) Covalent Inhibition of Ubc13 Affects Ubiquitin Signaling and Reveals Active Site Elements Important for Targeting. ACS Chem Biol 10:1718-1728. https://doi.org/10.1021/acschembio.5b00222 
162. Strickson S, Campbell DG, Emmerich CH, et al (2013) The anti-inflammatory drug BAY 11-7082 suppresses the MyD88-dependent signalling network by targeting the ubiquitin system. Biochem J 451:427-437. https://doi.org/10.1042/BJ20121651

163. Ceccarelli DF, Tang X, Pelletier B, et al (2011) An Allosteric Inhibitor of the Human Cdc34 Ubiquitin-Conjugating Cell 145:1075-1087. https://doi.org/10.1016/j.cell.2011.05.039

164. Huang H, Ceccarelli DF, Orlicky S, et al (2014) E2 enzyme inhibition by stabilization of a low affinity interface with ubiquitin. Nat Chem Biol 10:156-163. https://doi.org/10.1038/nchembio.1412

165. Sanders MA, Brahemi G, Nangia-Makker P, et al (2013) Novel inhibitors of Rad6 ubiquitin conjugating enzyme: design, synthesis, identification, and functional characterization. Mol Cancer Ther 12:373-383. https://doi.org/10.1158/1535-7163.MCT12-0793

166. Sanders MA, Haynes B, Nangia-Makker P, et al (2017) Pharmacological targeting of RAD6 enzyme-mediated translesion synthesis overcomes resistance to platinum-based drugs. J Biol Chem 292:10347-10363. https://doi.org/10.1074/jbc.M117.792192

167. Hirohama M, Kumar A, Fukuda I, et al (2013) Spectomycin B1 as a Novel SUMOylation Inhibitor That Directly Binds to SUMO E2. ACS Chem Biol. https://doi.org/10.1021/cb400630z

168. Nomura Y, Thuaud F, Sekine D, et al (2019) Synthesis of All Stereoisomers of Monomeric Spectomycin A1/A2 and Evaluation of Their Protein SUMOylation-Inhibitory Activity. Chem Weinh Bergstr Ger. https://doi.org/10.1002/chem.201901093

169. Kim YS, Nagy K, Keyser S, Schneekloth Jr. JS (2013) An Electrophoretic Mobility Shift Assay Identifies a Mechanistically Unique Inhibitor of Protein Sumoylation. Chem Biol 20:604-613. https://doi.org/10.1016/j.chembiol.2013.04.001

170. Baik H, Boulanger M, Hosseini M, et al (2018) Targeting the SUMO Pathway Primes Alltrans Retinoic Acid-Induced Differentiation of Nonpromyelocytic Acute Myeloid Leukemias. Cancer Res 78:2601-2613. https://doi.org/10.1158/0008-5472.CAN-17-3361

171. Wertz IE, Wang X (2019) From Discovery to Bedside: Targeting the Ubiquitin System. Cell Chem Biol 26:156-177. https://doi.org/10.1016/j.chembiol.2018.10.022

172. Gupta A, Shah K, Oza MJ, Behl T (2019) Reactivation of p53 gene by MDM2 inhibitors: A novel therapy for cancer treatment. Biomed Pharmacother 109:484-492. https://doi.org/10.1016/j.biopha.2018.10.155

173. Vassilev LT, Vu BT, Graves B, et al (2004) In Vivo Activation of the p53 Pathway by Small-Molecule Antagonists of MDM2. Science 303:844-848. https://doi.org/10.1126/science.1092472 
174. Ray-Coquard I, Blay J-Y, Italiano A, et al (2012) Effect of the MDM2 antagonist RG7112 on the P53 pathway in patients with MDM2-amplified, well-differentiated or dedifferentiated liposarcoma: an exploratory proof-of-mechanism study. Lancet Oncol 13:1133-1140. https://doi.org/10.1016/S1470-2045(12)70474-6

175. Andreeff M, Kelly KR, Yee K, et al (2016) Results of the Phase I Trial of RG7112, a Small-Molecule MDM2 Antagonist in Leukemia. Clin Cancer Res 22:868-876. https://doi.org/10.1158/1078-0432.CCR-15-0481

176. Shangary S, Qin D, McEachern D, et al (2008) Temporal activation of p53 by a specific MDM2 inhibitor is selectively toxic to tumors and leads to complete tumor growth inhibition. Proc Natl Acad Sci 105:3933-3938. https://doi.org/10.1073/pnas.0708917105

177. Sun D, Li Z, Rew Y, et al (2014) Discovery of AMG 232, a Potent, Selective, and Orally Bioavailable MDM2-p53 Inhibitor in Clinical Development. J Med Chem 57:1454-1472. https://doi.org/10.1021/jm401753e

178. Liao G, Yang D, Ma L, et al (2018) The development of piperidinones as potent MDM2P53 protein-protein interaction inhibitors for cancer therapy. Eur J Med Chem 159:1-9. https://doi.org/10.1016/j.ejmech.2018.09.044

179. Klein M (2017) Stabilized helical peptides: overview of the technologies and its impact on drug discovery. Expert Opin Drug Discov 1-9. https://doi.org/10.1080/17460441.2017.1372745

180. Carvajal LA, Neriah DB, Senecal A, et al (2018) Dual inhibition of MDMX and MDM2 as a therapeutic strategy in leukemia. Sci Transl Med 10:eaao3003. https://doi.org/10.1126/scitranslmed.aao3003

181. Fulda S (2017) Chapter Four - Smac Mimetics to Therapeutically Target IAP Proteins in Cancer. In: Galluzzi L (ed) International Review of Cell and Molecular Biology. Academic Press, pp 157-169

182. McComb S, Aguadé-Gorgorió J, Harder L, et al (2016) Activation of concurrent apoptosis and necroptosis by SMAC mimetics for the treatment of refractory and relapsed ALL. Sci Transl Med 8:339ra70-339ra70. https://doi.org/10.1126/scitranslmed.aad2986

183. Carter BZ, Mak PY, Mak DH, et al (2014) Synergistic Targeting of AML Stem/Progenitor Cells With IAP Antagonist Birinapant and Demethylating Agents. J Natl Cancer Inst 106:djt440. https://doi.org/10.1093/jnci/djt440

184. Amaravadi RK, Schilder RJ, Martin LP, et al (2015) A Phase I Study of the SMACMimetic Birinapant in Adults with Refractory Solid Tumors or Lymphoma. Mol Cancer Ther 14:2569-2575. https://doi.org/10.1158/1535-7163.MCT-15-0475

185. Infante JR, Dees EC, Olszanski AJ, et al (2014) Phase I Dose-Escalation Study of LCL161, an Oral Inhibitor of Apoptosis Proteins Inhibitor, in Patients With Advanced Solid Tumors. J Clin Oncol 32:3103-3110. https://doi.org/10.1200/JCO.2013.52.3993 
186. Saldana M, VanderVorst K, Berg AL, et al (2019) Otubain 1: a non-canonical deubiquitinase with an emerging role in cancer. Endocr Relat Cancer 26:R1-R14. https://doi.org/10.1530/ERC-18-0264

187. Moore MD, Finnerty B, Gray KD, et al (2018) Decreased UCHL1 expression as a cytologic biomarker for aggressive behavior in pancreatic neuroendocrine tumors. Surgery 163:226-231. https://doi.org/10.1016/j.surg.2017.04.040

188. Song JS, Yi JM, Cho H, et al (2018) Dual loss of USP10 and p14ARF protein expression is associated with poor prognosis in patients with small intestinal adenocarcinoma. Tumour Biol J Int Soc Oncodevelopmental Biol Med 40:1010428318808678. https://doi.org/10.1177/1010428318808678

189. Sun J, Li T, Zhao Y, et al (2018) USP10 inhibits lung cancer cell growth and invasion by upregulating PTEN. Mol Cell Biochem 441:1-7. https://doi.org/10.1007/s11010-017$3170-2$

190. Tan Y, Zhou G, Wang X, et al (2018) USP18 promotes breast cancer growth by upregulating EGFR and activating the AKT/Skp2 pathway. Int J Oncol 53:371-383. https://doi.org/10.3892/ijo.2018.4387

191. Li Y, Yang Y, Li J, et al (2017) USP22 drives colorectal cancer invasion and metastasis via epithelial-mesenchymal transition by activating AP4. Oncotarget 8:32683-32695. https://doi.org/10.18632/oncotarget.15950

192. Kim D, Hong A, Park HI, et al (2017) Deubiquitinating enzyme USP22 positively regulates c-Myc stability and tumorigenic activity in mammalian and breast cancer cells. J Cell Physiol 232:3664-3676. https://doi.org/10.1002/jcp.25841

193. Fang C-L, Lin C-C, Chen H-K, et al (2018) Ubiquitin-specific protease 3 overexpression promotes gastric carcinogenesis and is predictive of poor patient prognosis. Cancer Sci 109:3438-3449. https://doi.org/10.1111/cas.13789

194. Hu W, Wei H, Li K, et al (2017) Downregulation of USP32 inhibits cell proliferation, migration and invasion in human small cell lung cancer. Cell Prolif 50: https://doi.org/10.1111/cpr.12343

195. Chen Y, Pang X, Ji L, et al (2018) Reduced Expression of Deubiquitinase USP33 Is Associated with Tumor Progression and Poor Prognosis of Gastric Adenocarcinoma. Med Sci Monit Int Med J Exp Clin Res 24:3496-3505. https://doi.org/10.12659/MSM.908075

196. Li C, Huang $\mathrm{L}$, Lu H, et al (2018) Expression and clinical significance of ubiquitin- specific- processing protease 34 in diffuse large B- cell lymphoma. Mol Med Rep 18:4543-4554. https://doi.org/10.3892/mmr.2018.9447

197. Qin T, Li B, Feng X, et al (2018) Abnormally elevated USP37 expression in breast cancer stem cells regulates stemness, epithelial-mesenchymal transition and cisplatin sensitivity. J Exp Clin Cancer Res CR 37:287. https://doi.org/10.1186/s13046-018-0934-9 
198. Xu Y, Zhu M-R, Zhang J-Y, et al (2018) Knockdown of ubiquitin- specific peptidase 39 inhibits the malignant progression of human renal cell carcinoma. Mol Med Rep 17:47294735. https://doi.org/10.3892/mmr.2018.8421

199. Fraile JM, Manchado E, Lujambio A, et al (2017) USP39 Deubiquitinase Is Essential for KRAS Oncogene-driven Cancer. J Biol Chem 292:4164-4175. https://doi.org/10.1074/jbc.M116.762757

200. Yuan X, Sun X, Shi X, et al (2017) USP39 promotes colorectal cancer growth and metastasis through the Wnt/ $\beta$-catenin pathway. Oncol Rep 37:2398-2404. https://doi.org/10.3892/or.2017.5454

201. Guo W, Ma J, Pei T, et al (2018) Up-regulated deubiquitinase USP4 plays an oncogenic role in melanoma. J Cell Mol Med 22:2944-2954. https://doi.org/10.1111/jcmm.13603

202. Luo $\mathrm{K}$, Li Y, Yin Y, et al (2017) USP49 negatively regulates tumorigenesis and chemoresistance through FKBP51-AKT signaling. EMBO J 36:1434-1446. https://doi.org/10.15252/embj.201695669

203. Li X-Y, Wu H-Y, Mao X-F, et al (2017) USP5 promotes tumorigenesis and progression of pancreatic cancer by stabilizing FoxM1 protein. Biochem Biophys Res Commun 492:4854. https://doi.org/10.1016/j.bbrc.2017.08.040

204. Zhan M, Sun X, Liu J, et al (2017) Usp7 promotes medulloblastoma cell survival and metastasis by activating Shh pathway. Biochem Biophys Res Commun 484:429-434. https://doi.org/10.1016/j.bbrc.2017.01.144

205. Zeng Q, Li Z, Zhao X, et al (2019) Ubiquitin- specific protease 7 promotes osteosarcoma cell metastasis by inducing epithelial- mesenchymal transition. Oncol Rep 41:543-551. https://doi.org/10.3892/or.2018.6835

206. Yan M, Zhao C, Wei N, et al (2018) High Expression of Ubiquitin-Specific Protease 8 (USP8) Is Associated with Poor Prognosis in Patients with Cervical Squamous Cell Carcinoma. Med Sci Monit Int Med J Exp Clin Res 24:4934-4943. https://doi.org/10.12659/MSM.909235

207. Liu L, Yao D, Zhang P, et al (2017) Deubiquitinase USP9X promotes cell migration, invasion and inhibits apoptosis of human pancreatic cancer. Oncol Rep 38:3531-3537. https://doi.org/10.3892/or.2017.6050

208. Li X, Song N, Liu L, et al (2017) USP9X regulates centrosome duplication and promotes breast carcinogenesis. Nat Commun 8:14866. https://doi.org/10.1038/ncomms14866

209. Zhou C, Bi F, Yuan J, et al (2018) Gain of UBE2D1 facilitates hepatocellular carcinoma progression and is associated with DNA damage caused by continuous IL-6. J Exp Clin Cancer Res CR 37:290. https://doi.org/10.1186/s13046-018-0951-8 
210. Ma X, Zhao J, Yang F, et al (2017) Ubiquitin conjugating enzyme E2 L3 promoted tumor growth of NSCLC through accelerating p27kip1 ubiquitination and degradation. Oncotarget 8:84193-84203. https://doi.org/10.18632/oncotarget.20449

211. Pan Y-H, Yang M, Liu L-P, et al (2018) UBE2S enhances the ubiquitination of p53 and exerts oncogenic activities in hepatocellular carcinoma. Biochem Biophys Res Commun 503:895-902. https://doi.org/10.1016/j.bbrc.2018.06.093

212. Liu L-P, Yang M, Peng Q-Z, et al (2017) UBE2T promotes hepatocellular carcinoma cell growth via ubiquitination of p53. Biochem Biophys Res Commun 493:20-27. https://doi.org/10.1016/j.bbrc.2017.09.091

213. Luo C, Yao Y, Yu Z, et al (2017) UBE2T knockdown inhibits gastric cancer progression. Oncotarget 8:32639-32654. https://doi.org/10.18632/oncotarget.15947

214. Vila IK, Yao Y, Kim G, et al (2017) A UBE2O-AMPKa2 Axis that Promotes Tumor Initiation and Progression Offers Opportunities for Therapy. Cancer Cell 31:208-224. https://doi.org/10.1016/j.ccell.2017.01.003

215. Ullah K, Zubia E, Narayan M, et al (2018) Diverse roles of the E2/E3 hybrid enzyme UBE2O in the regulation of protein ubiquitination, cellular functions, and disease onset. FEBS J. https://doi.org/10.1111/febs. 14708

216. Jiang X, Li C, Lin B, et al (2017) cIAP2 promotes gallbladder cancer invasion and lymphangiogenesis by activating the NF- $\mathrm{KB}$ pathway. Cancer Sci 108:1144-1156. https://doi.org/10.1111/cas.13236

217. Dornan D, Bheddah S, Newton K, et al (2004) COP1, the Negative Regulator of p53, Is Overexpressed in Breast and Ovarian Adenocarcinomas. Cancer Res 64:7226-7230. https://doi.org/10.1158/0008-5472.CAN-04-2601

218. Marine J-C (2012) Spotlight on the role of COP1 in tumorigenesis. Nat Rev Cancer 12:455-464. https://doi.org/10.1038/nrc3271

219. Michail O, Moris D, Theocharis S, Griniatsos J (2018) Cullin-1 and -2 Protein Expression in Colorectal Cancer: Correlation with Clinicopathological Variables. Vivo Athens Greece 32:391-396. https://doi.org/10.21873/invivo.11251

220. Zeng R, Tan G, Li W, Ma Y (2018) Increased Expression of Cullin 3 in Nasopharyngeal Carcinoma and Knockdown Inhibits Proliferation and Invasion. Oncol Res 26:111-122. https://doi.org/10.3727/096504017X14924753593574

221. Raghu D, Paul PJ, Gulati T, et al (2017) E6AP promotes prostate cancer by reducing p27 expression. Oncotarget 8:42939-42948. https://doi.org/10.18632/oncotarget.17224

222. Paul PJ, Raghu D, Chan A-L, et al (2016) Restoration of tumor suppression in prostate cancer by targeting the E3 ligase E6AP. Oncogene 35:6235-6245. https://doi.org/10.1038/onc.2016.159 
223. Gamell C, Gulati T, Levav-Cohen Y, et al (2017) Reduced abundance of the E3 ubiquitin ligase E6AP contributes to decreased expression of the INK4/ARF locus in non-small cell lung cancer. Sci Signal 10:eaaf8223. https://doi.org/10.1126/scisignal.aaf8223

224. Sun C, Tao Y, Gao Y, et al (2018) F-box protein 11 promotes the growth and metastasis of gastric cancer via PI3K/AKT pathway-mediated EMT. Biomed Pharmacother Biomedecine Pharmacother 98:416-423. https://doi.org/10.1016/j.biopha.2017.12.088

225. Khan M, Muzumdar D, Shiras A (2019) Attenuation of Tumor Suppressive Function of FBXO16 Ubiquitin Ligase Activates Wnt Signaling In Glioblastoma. Neoplasia N Y N 21:106-116. https://doi.org/10.1016/j.neo.2018.11.005

226. Suber TL, Nikolli I, O'Brien ME, et al (2018) FBXO17 promotes cell proliferation through activation of Akt in lung adenocarcinoma cells. Respir Res 19:206. https://doi.org/10.1186/s12931-018-0910-0

227. Zou S, Ma C, Yang F, et al (2018) FBXO31 Suppresses Gastric Cancer EMT by Targeting Snaill for Proteasomal Degradation. Mol Cancer Res MCR 16:286-295. https://doi.org/10.1158/1541-7786.MCR-17-0432

228. Zhou H, Liu Y, Zhu R, et al (2017) FBXO32 suppresses breast cancer tumorigenesis through targeting KLF4 to proteasomal degradation. Oncogene 36:3312-3321. https://doi.org/10.1038/onc.2016.479

229. Yeh C-H, Bellon M, Nicot C (2018) FBXW7: a critical tumor suppressor of human cancers. Mol Cancer 17:115. https://doi.org/10.1186/s12943-018-0857-2

230. Kao S-H, Wu H-T, Wu K-J (2018) Ubiquitination by HUWE1 in tumorigenesis and beyond. J Biomed Sci 25:67. https://doi.org/10.1186/s12929-018-0470-0

231. Sampath D, Calin GA, Puduvalli VK, et al (2009) Specific activation of microRNA106b enables the p73 apoptotic response in chronic lymphocytic leukemia by targeting the ubiquitin ligase Itch for degradation. Blood 113:3744-3753. https://doi.org/10.1182/blood2008-09-178707

232. Salah Z, Melino G, Aqeilan RI (2011) Negative Regulation of the Hippo Pathway by E3 Ubiquitin Ligase ITCH Is Sufficient to Promote Tumorigenicity. Cancer Res 71:20102020. https://doi.org/10.1158/0008-5472.CAN-10-3516

233. Salah Z, Itzhaki E, Aqeilan RI (2014) The ubiquitin E3 ligase ITCH enhances breast tumor progression by inhibiting the Hippo tumor suppressor pathway. Oncotarget 5:1088610900. https://doi.org/10.18632/oncotarget.2540

234. Li P-F, Zhang Q-G (2018) Inhibition of ITCH Suppresses Proliferation and Induces Apoptosis of Lung Cancer Cells. Cell Physiol Biochem Int J Exp Cell Physiol Biochem Pharmacol 48:1703-1709. https://doi.org/10.1159/000492295 
235. Steklov M, Pandolfi S, Baietti MF, et al (2018) Mutations in LZTR1 drive human disease by dysregulating RAS ubiquitination. Science 362:1177-1182. https://doi.org/10.1126/science.aap7607

236. Mayo LD, Dixon JE, Durden DL, et al (2002) PTEN Protects p53 from Mdm2 and Sensitizes Cancer Cells to Chemotherapy. J Biol Chem 277:5484-5489. https://doi.org/10.1074/jbc.M108302200

237. Wade M, Li Y-C, Wahl GM (2013) MDM2, MDMX and p53 in oncogenesis and cancer therapy. Nat Rev Cancer 13:83-96. https://doi.org/10.1038/nrc3430

238. Laurie NA, Donovan SL, Shih C-S, et al (2006) Inactivation of the p53 pathway in retinoblastoma. Nature 444:61. https://doi.org/10.1038/nature05194

239. Shao G, Wang R, Sun A, et al (2018) The E3 ubiquitin ligase NEDD4 mediates cell migration signaling of EGFR in lung cancer cells. Mol Cancer 17:24. https://doi.org/10.1186/s12943-018-0784-2

240. Wen W, Li J, Wang L, et al (2017) Inhibition of NEDD4 inhibits cell growth and invasion and induces cell apoptosis in bladder cancer cells. Cell Cycle Georget Tex 16:1509-1514. https://doi.org/10.1080/15384101.2017.1338220

241. Weng M, Luo Z-L, Wu X-L, Zeng W-Z (2017) The E3 ubiquitin ligase NEDD4 is translationally upregulated and facilitates pancreatic cancer. Oncotarget 8:20288-20296. https://doi.org/10.18632/oncotarget.15446

242. Eide PW, Cekaite L, Danielsen SA, et al (2013) NEDD4 is overexpressed in colorectal cancer and promotes colonic cell growth independently of the PI3K/PTEN/AKT pathway. Cell Signal 25:12-18. https://doi.org/10.1016/j.cellsig.2012.08.012

243. Kito Y, Bai J, Goto N, et al (2014) Pathobiological properties of the ubiquitin ligase Nedd4L in melanoma. Int J Exp Pathol 95:24-28. https://doi.org/10.1111/iep.12051

244. Qu M-H, Han C, Srivastava AK, et al (2016) miR-93 promotes TGF- $\beta$-induced epithelialto-mesenchymal transition through downregulation of NEDD4L in lung cancer cells. Tumour Biol J Int Soc Oncodevelopmental Biol Med 37:5645-5651. https://doi.org/10.1007/s13277-015-4328-8

245. Tanksley JP, Chen X, Coffey RJ (2013) NEDD4L is downregulated in colorectal cancer and inhibits canonical WNT signaling. PloS One 8:e81514. https://doi.org/10.1371/journal.pone.0081514

246. Zhao R, Cui T, Han C, et al (2015) DDB2 modulates TGF- $\beta$ signal transduction in human ovarian cancer cells by downregulating NEDD4L. Nucleic Acids Res 43:7838-7849. https://doi.org/10.1093/nar/gkv667 
247. Hu XY, Xu YM, Fu Q, et al (2009) Nedd4L expression is downregulated in prostate cancer compared to benign prostatic hyperplasia. Eur J Surg Oncol J Eur Soc Surg Oncol Br Assoc Surg Oncol 35:527-531. https://doi.org/10.1016/j.ejso.2008.09.015

248. Bao Y, Wu X, Yuan D, et al (2017) High Expression of Pirh2 is Associated with Poor Prognosis in Glioma. Cell Mol Neurobiol 37:1501-1509. https://doi.org/10.1007/s10571017-0481-5

249. Logan IR, Gaughan L, McCracken SRC, et al (2006) Human PIRH2 Enhances Androgen Receptor Signaling through Inhibition of Histone Deacetylase 1 and Is Overexpressed in Prostate Cancer. Mol Cell Biol 26:6502-6510. https://doi.org/10.1128/MCB.00147-06

250. Shimada M, Kitagawa K, Dobashi Y, et al (2009) High expression of Pirh2, an E3 ligase for $\mathrm{p} 27$, is associated with low expression of p27 and poor prognosis in head and neck cancers. Cancer Sci 100:866-872

251. Duan W, Gao L, Druhan LJ, et al (2004) Expression of Pirh2, a Newly Identified Ubiquitin Protein Ligase, in Lung Cancer. JNCI J Natl Cancer Inst 96:1718-1721. https://doi.org/10.1093/jnci/djh292

252. Wang X-M, Yang L-Y, Guo L, et al (2009) p53-induced RING-H2 protein, a novel marker for poor survival in hepatocellular carcinoma after hepatic resection. Cancer 115:45544563. https://doi.org/10.1002/cncr.24494

253. Wu H, Li X, Feng M, et al (2018) Downregulation of RNF138 inhibits cellular proliferation, migration, invasion and EMT in glioma cells via suppression of the Erk signaling pathway. Oncol Rep 40:3285-3296. https://doi.org/10.3892/or.2018.6744

254. Shen J, Yu Z, Li N (2018) The E3 ubiquitin ligase RNF146 promotes colorectal cancer by activating the Wnt/ $\beta$-catenin pathway via ubiquitination of Axin1. Biochem Biophys Res Commun 503:991-997. https://doi.org/10.1016/j.bbrc.2018.06.107

255. Qiu D, Wang Q, Wang Z, et al (2018) RNF185 modulates JWA ubiquitination and promotes gastric cancer metastasis. Biochim Biophys Acta Mol Basis Dis 1864:15521561. https://doi.org/10.1016/j.bbadis.2018.02.013

256. Sethi G, Shanmugam MK, Arfuso F, Kumar AP (2018) Role of RNF20 in cancer development and progression - a comprehensive review. Biosci Rep 38:BSR20171287. https://doi.org/10.1042/BSR20171287

257. Gao Y, Cai A, Xi H, et al (2017) Ring finger protein 43 associates with gastric cancer progression and attenuates the stemness of gastric cancer stem-like cells via the Wnt$\beta /$ catenin signaling pathway. Stem Cell Res Ther 8:98. https://doi.org/10.1186/s13287017-0548-8

258. Xiao Y, Jiang Y, Song H, et al (2017) RNF7 knockdown inhibits prostate cancer tumorigenesis by inactivation of ERK1/2 pathway. Sci Rep 7:43683. https://doi.org/10.1038/srep43683 
259. Gopalsamy A, Hagen T, Swaminathan K (2014) Investigating the Molecular Basis of Siah1 and Siah2 E3 Ubiquitin Ligase Substrate Specificity. PLOS ONE 9:e106547. https://doi.org/10.1371/journal.pone.0106547

260. Jiang $X$, Shen $X$ (2018) Knockdown of miR-299-5p inhibits the progression of hepatocellular carcinoma by targeting SIAH1. Bull Cancer (Paris) 105:873-883. https://doi.org/10.1016/j.bulcan.2018.07.013

261. Hung W-C, Tseng W-L, Shiea J, Chang H-C (2010) Skp2 overexpression increases the expression of MMP-2 and MMP-9 and invasion of lung cancer cells. Cancer Lett 288:156161. https://doi.org/10.1016/j.canlet.2009.06.032

262. Lee S-W, Li C-F, Jin G, et al (2015) Skp2-Dependent Ubiquitination and Activation of LKB1 Is Essential for Cancer Cell Survival under Energy Stress. Mol Cell 57:1022-1033. https://doi.org/10.1016/j.molcel.2015.01.015

263. Tosco P, La Terra Maggiore GM, Forni P, et al (2011) Correlation between Skp2 expression and nodal metastasis in stage I and II oral squamous cell carcinomas. Oral Dis 17:102-108. https://doi.org/10.1111/j.1601-0825.2010.01713.x

264. Saigusa K, Hashimoto N, Tsuda H, et al (2005) Overexpressed Skp2 within 5p amplification detected by array-based comparative genomic hybridization is associated with poor prognosis of glioblastomas. Cancer Sci 96:676-683. https://doi.org/10.1111/j.1349-7006.2005.00099.x

265. Loukopoulos P, Shibata T, Katoh H, et al (2007) Genome-wide array-based comparative genomic hybridization analysis of pancreatic adenocarcinoma: Identification of genetic indicators that predict patient outcome. Cancer Sci 98:392-400. https://doi.org/10.1111/j.1349-7006.2007.00395.x

266. Tao Y, Sun C, Zhang T, Song Y (2017) SMURF1 promotes the proliferation, migration and invasion of gastric cancer cells. Oncol Rep 38:1806-1814. https://doi.org/10.3892/or.2017.5825

267. Yan C, Su H, Song X, et al (2018) Smad Ubiquitination Regulatory Factor 1 (Smurf1) Promotes Thyroid Cancer Cell Proliferation and Migration via Ubiquitin-Dependent Degradation of Kisspeptin-1. Cell Physiol Biochem 49:2047-2059. https://doi.org/10.1159/000493715

268. Chang H, Zhang J, Miao Z, et al (2018) Suppression of the Smurf1 Expression Inhibits Tumor Progression in Gliomas. Cell Mol Neurobiol 38:421-430. https://doi.org/10.1007/s10571-017-0485-1

269. Wang W, Du H, Liu H, et al (2019) SMAD specific E3 ubiquitin protein ligase 1 promotes ovarian cancer cell migration and invasion via the activation of the RhoA/ROCK signaling pathway. Oncol Rep 41:668-676. https://doi.org/10.3892/or.2018.6836 
270. Fukuchi M, Fukai Y, Masuda N, et al (2002) High-level expression of the Smad ubiquitin ligase Smurf2 correlates with poor prognosis in patients with esophageal squamous cell carcinoma. Cancer Res 62:7162-7165

271. Jin C, Yang Y, Anver MR, et al (2009) Smad Ubiquitination Regulatory Factor 2 Promotes Metastasis of Breast Cancer Cells by Enhancing Migration and Invasiveness. Cancer Res 69:735-740. https://doi.org/10.1158/0008-5472.CAN-08-1463

272. Fukasawa H, Yamamoto T, Fujigaki Y, et al (2010) Reduction of transforming growth factor- $\beta$ type II receptor is caused by the enhanced ubiquitin-dependent degradation in human renal cell carcinoma. Int J Cancer 127:1517-1525. https://doi.org/10.1002/ijc.25164

273. Chen Y, Li L, Qian X, et al (2017) High expression of TRIM11 correlates with poor prognosis in patients with hepatocellular carcinoma. Clin Res Hepatol Gastroenterol 41:190-196. https://doi.org/10.1016/j.clinre.2016.09.010

274. Zhang Z, Xu C, Zhang X, et al (2017) TRIM11 Upregulation Contributes to Proliferation, Invasion, and EMT of Hepatocellular Carcinoma Cells. Oncol Res 25:691-699. https://doi.org/10.3727/096504016X14774897404770

275. Pan Y, Zhang R, Chen H, et al (2019) Expression of Tripartite Motif-Containing Proteactiin 11 (TRIM11) is Associated with the Progression of Human Prostate Cancer and is Downregulated by MicroRNA-5193. Med Sci Monit Int Med J Exp Clin Res 25:98-106. https://doi.org/10.12659/MSM.911818

276. Qin X, Qiu F, Zou Z (2017) TRIM25 is associated with cisplatin resistance in non-smallcell lung carcinoma A549 cell line via downregulation of 14-3-3 $\sigma$. Biochem Biophys Res Commun 493:568-572. https://doi.org/10.1016/j.bbrc.2017.08.151

277. Sun N, Xue Y, Dai T, et al (2017) Tripartite motif containing 25 promotes proliferation and invasion of colorectal cancer cells through TGF- $\beta$ signaling. Biosci Rep 37:. https://doi.org/10.1042/BSR20170805

278. Takayama K-I, Suzuki T, Tanaka T, et al (2018) TRIM25 enhances cell growth and cell survival by modulating p53 signals via interaction with G3BP2 in prostate cancer. Oncogene 37:2165-2180. https://doi.org/10.1038/s41388-017-0095-x

279. Zang H-L, Ren S-N, Cao H, Tian X-F (2017) The ubiquitin ligase TRIM25 inhibits hepatocellular carcinoma progression by targeting metastasis associated 1 protein. IUBMB Life 69:795-801. https://doi.org/10.1002/iub.1661

280. Fong K, Zhao JC, Song B, et al (2018) TRIM28 protects TRIM24 from SPOP-mediated degradation and promotes prostate cancer progression. Nat Commun 9:5007. https://doi.org/10.1038/s41467-018-07475-5

281. Li H, Zhang Y, Hai J, et al (2018) Knockdown of TRIM31 suppresses proliferation and invasion of gallbladder cancer cells by down-regulating MMP2/9 through the PI3K/Akt 
signaling pathway. Biomed Pharmacother Biomedecine Pharmacother 103:1272-1278. https://doi.org/10.1016/j.biopha.2018.04.120

282. Guo P, Ma X, Zhao W, et al (2018) TRIM31 is upregulated in hepatocellular carcinoma and promotes disease progression by inducing ubiquitination of TSC1-TSC2 complex. Oncogene 37:478-488. https://doi.org/10.1038/onc.2017.349

283. Zhang J, Zhang C, Cui J, et al (2017) TRIM45 functions as a tumor suppressor in the brain via its E3 ligase activity by stabilizing p53 through K63-linked ubiquitination. Cell Death Dis 8:e2831. https://doi.org/10.1038/cddis.2017.149

284. Chen Y, Zhao J, Li D, et al (2018) TRIM56 Suppresses Multiple Myeloma Progression by Activating TLR3/TRIF Signaling. Yonsei Med J 59:43-50. https://doi.org/10.3349/ymj.2018.59.1.43

285. Zhao L, Zhang P, Su X-J, Zhang B (2018) The ubiquitin ligase TRIM56 inhibits ovarian cancer progression by targeting vimentin. J Cell Physiol 233:2420-2425. https://doi.org/10.1002/jcp.26114

286. Liao L, Song M, Li X, et al (2017) E3 Ubiquitin Ligase UBR5 Drives the Growth and Metastasis of Triple-Negative Breast Cancer. Cancer Res 77:2090-2101. https://doi.org/10.1158/0008-5472.CAN-16-2409

287. Chen C, Sun X, Guo P, et al (2007) Ubiquitin E3 ligase WWP1 as an oncogenic factor in human prostate cancer. Oncogene 26:2386-2394. https://doi.org/10.1038/sj.onc.1210021

288. Chen C, Zhou Z, Ross JS, et al (2007) The amplified WWP1 gene is a potential molecular target in breast cancer. Int J Cancer 121:80-87. https://doi.org/10.1002/ijc.22653

289. Sanarico AG, Ronchini C, Croce A, et al (2018) The E3 ubiquitin ligase WWP1 sustains the growth of acute myeloid leukaemia. Leukemia 32:911-919. https://doi.org/10.1038/leu.2017.342

290. Wu Z, Zan P, Li S, et al (2015) Knockdown of WWP1 inhibits growth and invasion, but induces apoptosis of osteosarcoma cells. Int J Clin Exp Pathol 8:7869-7877

291. Zhang L, Wu Z, Ma Z, et al (2015) WWP1 as a potential tumor oncogene regulates PTENAkt signaling pathway in human gastric carcinoma. Tumor Biol 36:787-798. https://doi.org/10.1007/s13277-014-2696-0

292. Yang R, He Y, Chen S, et al (2016) Elevated expression of WWP2 in human lung adenocarcinoma and its effect on migration and invasion. Biochem Biophys Res Commun 479:146-151. https://doi.org/10.1016/j.bbrc.2016.07.084

293. Liang J, Qi W-F, Xie S, et al (2017) Expression of WW domain-containing protein 2 is correlated with pathological grade and recurrence of glioma. J Cancer Res Ther 13:10321037. https://doi.org/10.4103/0973-1482.176176 
294. Liu K, Zhang J, Wang H (2018) Small ubiquitin-like modifier/sentrin-specific peptidase 1 associates with chemotherapy and is a risk factor for poor prognosis of non-small cell lung cancer. J Clin Lab Anal 32:e22611. https://doi.org/10.1002/jcla.22611

295. Zhou G-Q, Han F, Shi Z-L, et al (2018) miR-133a-3p Targets SUMO-Specific Protease 1 to Inhibit Cell Proliferation and Cell Cycle Progress in Colorectal Cancer. Oncol Res 26:795-800. https://doi.org/10.3727/096504017X15004613574679

296. Dong B, Gao Y, Kang X, et al (2016) SENP1 promotes proliferation of clear cell renal cell carcinoma through activation of glycolysis. Oncotarget 7:80435-80449. https://doi.org/10.18632/oncotarget.12606

297. Zhang W, Sun H, Shi X, et al (2016) SENP1 regulates hepatocyte growth factor-induced migration and epithelial-mesenchymal transition of hepatocellular carcinoma. Tumour Biol J Int Soc Oncodevelopmental Biol Med 37:7741-7748. https://doi.org/10.1007/s13277015-4406-y

298. Bawa-Khalfe T, Yang F-M, Ritho J, et al (2017) SENP1 regulates PTEN stability to dictate prostate cancer development. Oncotarget 8:17651-17664. https://doi.org/10.18632/oncotarget.13283

299. Wu J, Lei H, Zhang J, et al (2016) Momordin Ic, a new natural SENP1 inhibitor, inhibits prostate cancer cell proliferation. Oncotarget 7:58995-59005. https://doi.org/10.18632/oncotarget.10636

300. Sun X-X, Chen Y, Su Y, et al (2018) SUMO protease SENP1 deSUMOylates and stabilizes c-Myc. Proc Natl Acad Sci U S A 115:10983-10988. https://doi.org/10.1073/pnas.1802932115

301. Wang Z, Jin J, Zhang J, et al (2016) Depletion of SENP1 suppresses the proliferation and invasion of triple-negative breast cancer cells. Oncol Rep 36:2071-2078. https://doi.org/10.3892/or.2016.5036

302. Xia W, Tian H, Cai X, et al (2016) Inhibition of SUMO-specific protease 1 induces apoptosis of astroglioma cells by regulating NF-kB/Akt pathways. Gene 595:175-179. https://doi.org/10.1016/j.gene.2016.09.040

303. Wang X, Liang X, Liang H, Wang B (2018) SENP1/HIF-1 $\alpha$ feedback loop modulates hypoxia-induced cell proliferation, invasion, and EMT in human osteosarcoma cells. J Cell Biochem 119:1819-1826. https://doi.org/10.1002/jcb.26342

304. Liu F, Li L, Li Y, et al (2018) Overexpression of SENP1 reduces the stemness capacity of osteosarcoma stem cells and increases their sensitivity to HSVtk/GCV. Int J Oncol 53:2010-2020. https://doi.org/10.3892/ijo.2018.4537

305. Tan M, Zhang D, Zhang E, et al (2017) SENP2 suppresses epithelial-mesenchymal transition of bladder cancer cells through deSUMOylation of TGF- $\beta$ RI. Mol Carcinog 56:2332-2341. https://doi.org/10.1002/mc.22687 
306. Hu X-Y, Liu Z, Zhang K-L, et al (2017) SUMO-specific protease 2-mediated deSUMOylation is required for NDRG2 stabilization in gastric cancer cells. Cancer Biomark Sect Dis Markers 21:195-201. https://doi.org/10.3233/CBM-170651

307. Chen X-L, Wang S-F, Liang X-T, et al (2019) SENP2 exerts an anti- tumor effect on chronic lymphocytic leukemia cells through the inhibition of the Notch and NF- $\mathrm{kB}$ signaling pathways. Int J Oncol 54:455-466. https://doi.org/10.3892/ijo.2018.4635

308. Cheng J, Su M, Jin Y, et al (2017) Upregulation of SENP3/SMT3IP1 promotes epithelial ovarian cancer progression and forecasts poor prognosis. Tumour Biol J Int Soc Oncodevelopmental Biol Med 39:1010428317694543. https://doi.org/10.1177/1010428317694543

309. Jin Z-L, Pei H, Xu Y-H, et al (2016) The SUMO-specific protease SENP5 controls DNA damage response and promotes tumorigenesis in hepatocellular carcinoma. Eur Rev Med Pharmacol Sci 20:3566-3573

310. Cerami E, Gao J, Dogrusoz U, et al (2012) The cBio cancer genomics portal: an open platform for exploring multidimensional cancer genomics data. Cancer Discov 2:401-404. https://doi.org/10.1158/2159-8290.CD-12-0095

311. Li J, Sun X, He P, et al (2018) Ubiquitin-like modifier activating enzyme 2 promotes cell migration and invasion through $\mathrm{Wnt} / \beta$-catenin signaling in gastric cancer. World $\mathbf{J}$ Gastroenterol 24:4773-4786. https://doi.org/10.3748/wjg.v24.i42.4773

312. Fang S, Qiu J, Wu Z, et al (2017) Down-regulation of UBC9 increases the sensitivity of hepatocellular carcinoma to doxorubicin. Oncotarget 8:49783-49795. https://doi.org/10.18632/oncotarget.17939

313. Zhang D, Yu K, Yang Z, et al (2018) Silencing Ubc9 expression suppresses osteosarcoma tumorigenesis and enhances chemosensitivity to HSV-TK/GCV by regulating connexin 43 SUMOylation. Int J Oncol 53:1323-1331. https://doi.org/10.3892/ijo.2018.4448

314. Chanda A, Chan A, Deng L, et al (2017) Identification of the SUMO E3 ligase PIAS1 as a potential survival biomarker in breast cancer. PloS One 12:e0177639. https://doi.org/10.1371/journal.pone.0177639

315. Hoefer J, Schäfer G, Klocker H, et al (2012) PIAS1 is increased in human prostate cancer and enhances proliferation through inhibition of p21. Am J Pathol 180:2097-2107. https://doi.org/10.1016/j.ajpath.2012.01.026

316. Puhr M, Hoefer J, Eigentler A, et al (2016) PIAS1 is a determinant of poor survival and acts as a positive feedback regulator of AR signaling through enhanced AR stabilization in prostate cancer. Oncogene 35:2322-2332. https://doi.org/10.1038/onc.2015.292

317. Driscoll JJ, Pelluru D, Lefkimmiatis K, et al (2010) The sumoylation pathway is dysregulated in multiple myeloma and is associated with adverse patient outcome. Blood 115:2827-2834. https://doi.org/10.1182/blood-2009-03-211045 
318. Guo Z, Wang Y, Zhao Y, et al (2019) The pivotal oncogenic role of Jab1/CSN5 and its therapeutic implications in human cancer. Gene 687:219-227. https://doi.org/10.1016/j.gene.2018.11.061

319. Lee G-W, Park JB, Park SY, et al (2018) The E3 ligase C-CBL inhibits cancer cell migration by neddylating the proto-oncogene c-Src. Oncogene 37:5552-5568. https://doi.org/10.1038/s41388-018-0354-5 


\begin{tabular}{|c|c|c|c|c|c|c|}
\hline Modifier & $\begin{array}{l}\text { Homology } \\
\text { with } \\
\text { ubiquitin }\end{array}$ & E1 & E2 & E3 & Protease & Functions \\
\hline Ubiquitin & 100 & UBE1, UBA6 & 38 & $>600$ & $\sim 100$ & $\begin{array}{c}\text { Multiples, proteasomal } \\
\text { degradation }\end{array}$ \\
\hline SUM01-5 & 15 & SAE1/SAE2 & UBC9 & $>15$ & $\sim 10$ & $\begin{array}{l}\text { Protein/protein interaction, } \\
\text { regulation of transcription }\end{array}$ \\
\hline NEDD8 & 58 & NAE1/UBA3 & $\begin{array}{l}\text { UBC12, } \\
\text { UBE2F }\end{array}$ & $>10$ & $\begin{array}{l}\text { CSN5, } \\
\text { NEDP1 }\end{array}$ & Cullins activation, cell cycle \\
\hline ISG15 & 27 & UBE1L & UBCH8 & $\begin{array}{c}\text { HERC5, } \\
\text { EFP, } \\
\text { HHARI }\end{array}$ & USP18 & $\begin{array}{c}\text { Immune response, response } \\
\text { to stress }\end{array}$ \\
\hline FUB1 & 36 & & & & & $\begin{array}{l}\text { Unknown, immune response } \\
\text { regulation }\end{array}$ \\
\hline FAT10 & 27 & UBA6 & USE2 & & 0 & Proteasomal degradation \\
\hline URM1 & 17 & UBA4 & & & & $\begin{array}{l}\text { tRNA thiolation, oxydative } \\
\text { stress response }\end{array}$ \\
\hline UBL5 & 25 & & & & & $\begin{array}{l}\text { RNA splicing, cell } \\
\text { polarisation }\end{array}$ \\
\hline UFM1 & 23 & UBA5 & UFC1 & UFL1 & $\begin{array}{l}\text { UFSP1, } \\
\text { UFSP2 }\end{array}$ & $\begin{array}{c}\text { Hematopoiesis, } \mathrm{NF}-\kappa \mathrm{B} \\
\text { regulation }\end{array}$ \\
\hline ATG8 & & ATG7 & ATG3 & & ATG4 & Autophagy \\
\hline ATG12 & 12 & ATG7 & ATG10 & & 0 & Autophagy \\
\hline MAP1LC3A & 9 & \multirow{7}{*}{ ATG7 } & \multirow{7}{*}{ ATG3 } & \multirow{7}{*}{$\begin{array}{l}\text { ATG12, } \\
\text { ATG5, } \\
\text { ATG16L }\end{array}$} & \multirow{7}{*}{$\begin{array}{l}\text { ATG4A, } \\
\text { ATG4B, } \\
\text { ATG4C, } \\
\text { ATG4D }\end{array}$} & \multirow{7}{*}{ Autophagosomes formation } \\
\hline MAP1LC3B & 13 & & & & & \\
\hline MAP1LC3C & 10 & & & & & \\
\hline GABARAP & 8 & & & & & \\
\hline GABARAPL1 & 12 & & & & & \\
\hline GABARAPL2 & 14 & & & & & \\
\hline GABARAPL3 & & & & & & \\
\hline
\end{tabular}

Table 1: Ubiquitin-like modifiers: conjugation/deconjugation enzymes and main functions 


\begin{tabular}{|c|c|c|c|c|c|}
\hline $\mathrm{UbL}$ & $\begin{array}{c}\text { Enzym } \\
\mathrm{e}\end{array}$ & Enzyme & Dysregulation & Cancer & Reference \\
\hline \multirow{28}{*}{$\mathrm{Ub}$} & \multirow{18}{*}{ DUB } & OTUB1 & Overexpression & $\begin{array}{l}\text { lung, breast, } \\
\text { ovarian, glioma, } \\
\text { colon, gastric }\end{array}$ & [186] \\
\hline & & UCHL1 & Underexpression & pancreatic & [187] \\
\hline & & USP10 & Underexpression & $\begin{array}{l}\text { small intestinal } \\
\text { adenocarcinoma }\end{array}$ & [188] \\
\hline & & USP10 & Underexpression & lung & [189] \\
\hline & & USP18 & Overexpression & breast & [190] \\
\hline & & USP22 & Overexpression & $\begin{array}{c}\text { Colorectal, } \\
\text { breast }\end{array}$ & {$[191,192]$} \\
\hline & & USP3 & Overepression & gastric & [193] \\
\hline & & USP32 & Overexpression & SCL & [194] \\
\hline & & USP33 & Underexpression & gastric & [195] \\
\hline & & USP34 & Overepression & $\begin{array}{l}\text { Diffuse large B- } \\
\text { cell lymphoma }\end{array}$ & [196] \\
\hline & & USP37 & Overexpression & Breast & [197] \\
\hline & & USP39 & Overexpression & $\begin{array}{l}\text { Renal, colorectal, } \\
\text { lung }\end{array}$ & [198-200] \\
\hline & & USP4 & Overexpression & melanoma & [201] \\
\hline & & USP49 & Underexpression & pancreatic & [202] \\
\hline & & USP5 & Overexpression & Pancreatic & [203] \\
\hline & & USP7 & Overexpression & $\begin{array}{c}\text { Osteosarcoma, } \\
\text { medullo- } \\
\text { blastoma }\end{array}$ & {$[204,205]$} \\
\hline & & USP8 & Overexpression & cervical & [206] \\
\hline & & USP9X & Overexpression & $\begin{array}{c}\text { Pancreatic, } \\
\text { breast }\end{array}$ & {$[207,208]$} \\
\hline & \multirow{4}{*}{ E2 } & UBE2D1 & Overexpression & $\begin{array}{c}\text { Hepatocellular } \\
\text { carcinoma }\end{array}$ & [209] \\
\hline & & UBE2L3 & Overexpression & NSCL & [210] \\
\hline & & UBE2S & Overexpression & Hepatocellular & [211] \\
\hline & & UBE2T & Overexpression & $\begin{array}{c}\text { Hepatocellular, } \\
\text { gastric }\end{array}$ & {$[212,213]$} \\
\hline & E2/E3 & UBE20 & $\begin{array}{l}\text { Overexpression/ } \\
\text { mutation }\end{array}$ & $\begin{array}{c}\text { Gastric, lung, } \\
\text { breast, prostate, } \\
\text { colorectal, TNBC }\end{array}$ & {$[214,215]$} \\
\hline & \multirow{5}{*}{ E3 } & cIAP2 & Overexpression & Gallbladder & [216] \\
\hline & & COP1 & Overexpression & $\begin{array}{l}\text { Breast, ovarian, } \\
\text { leukemia, } \\
\text { melanoma, lung }\end{array}$ & {$[217,218]$} \\
\hline & & CUL-1 & Overexpression & colorectal & [219] \\
\hline & & CUL-2 & Overexpression & colorectal & [219] \\
\hline & & CUL-3 & Overexpression & nasopharyngeal & [220] \\
\hline
\end{tabular}




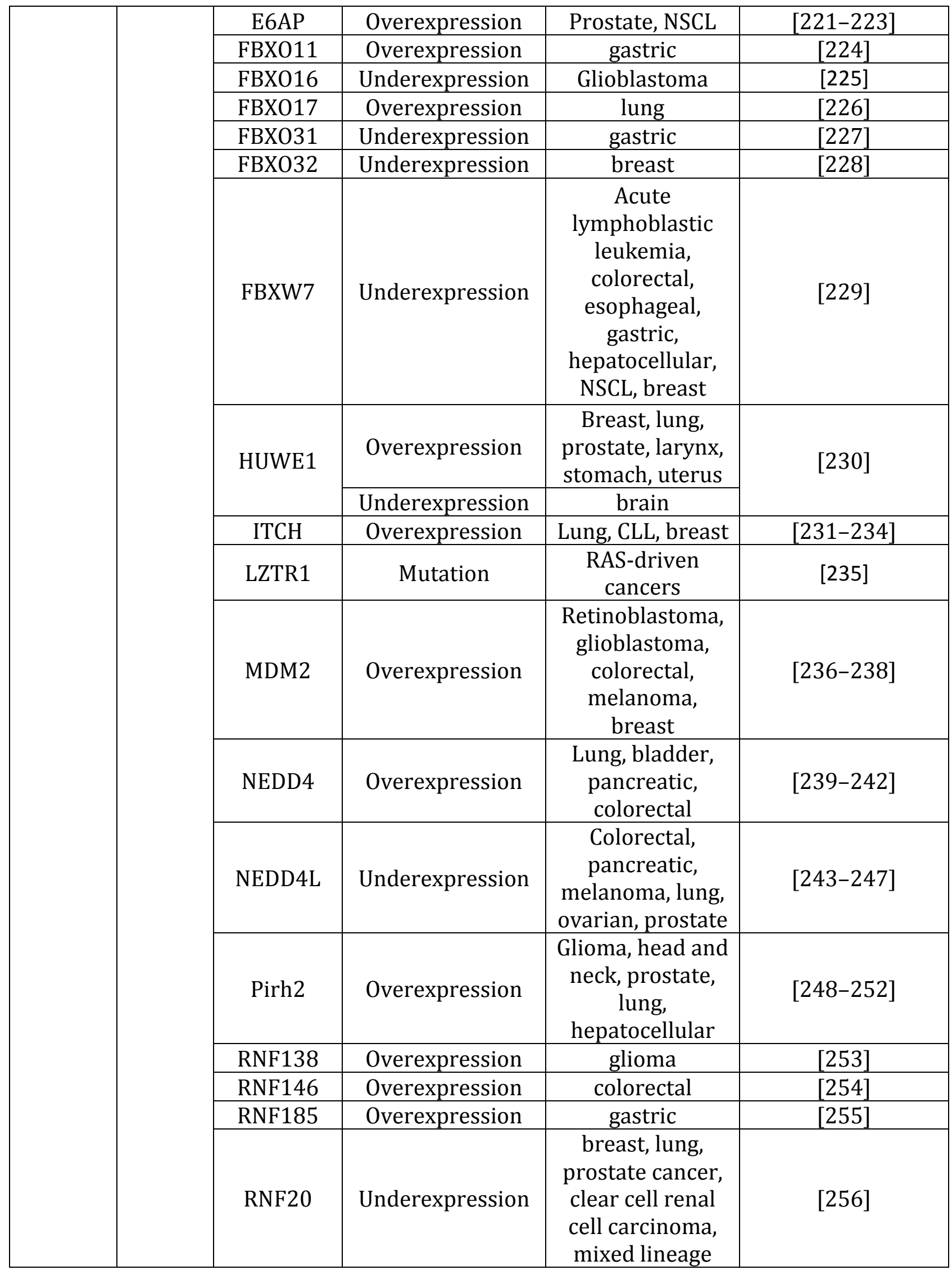




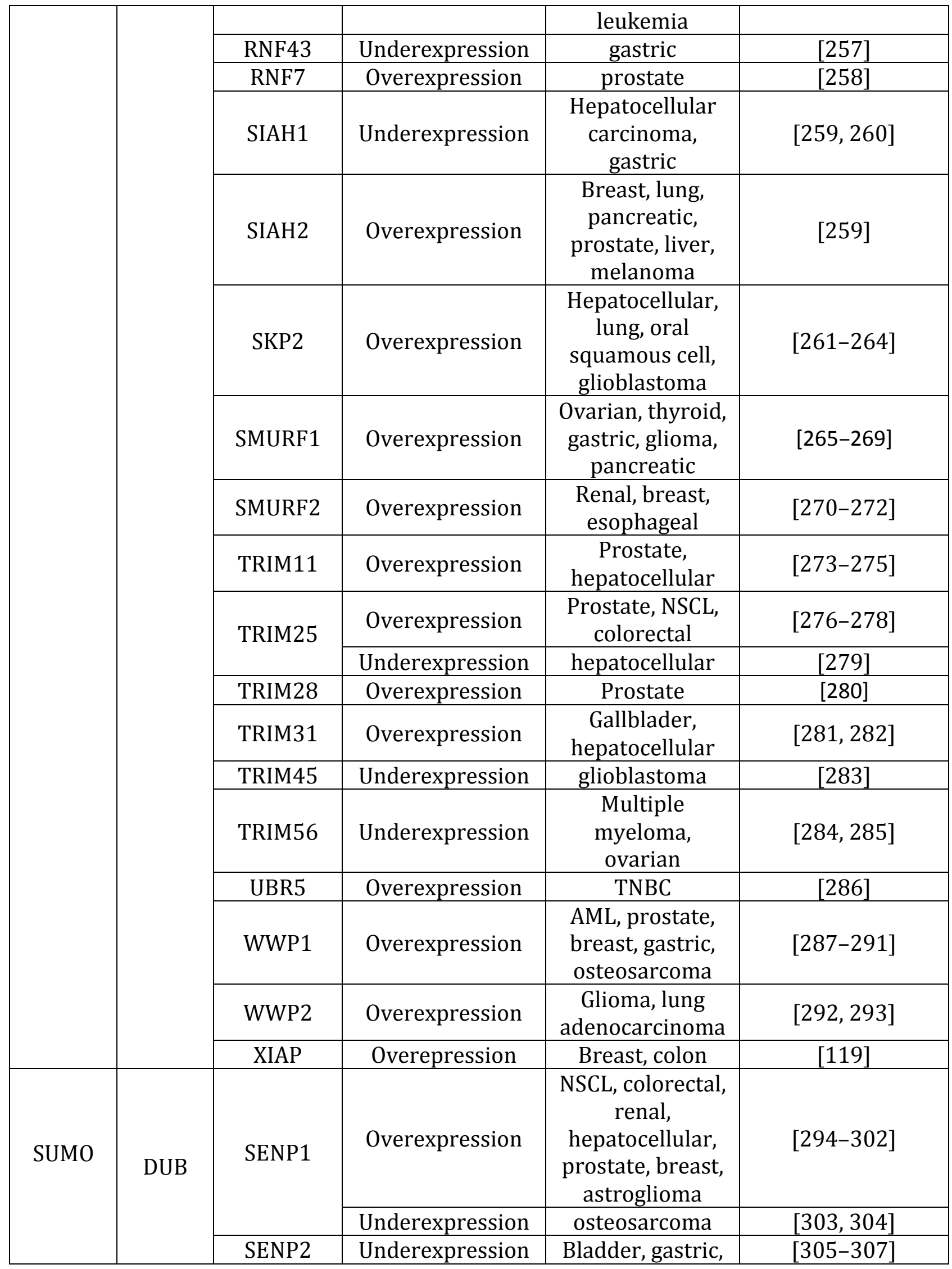




\begin{tabular}{|c|c|c|c|c|c|}
\hline & & & & $\begin{array}{c}\text { chronic } \\
\text { lymphocytic } \\
\text { leukemia }\end{array}$ & \\
\hline & & SENP3 & Overexpression & ovarian & [308] \\
\hline & & SENP5 & Overexpression & hepatocellular & [309] \\
\hline & E1 & SAE1/2 & Overexpression & $\begin{array}{c}\text { Gastric, } \\
\text { colorectal, } \\
\text { breast, prostate, } \\
\text { pancreatic, } \\
\text { hepatocellular }\end{array}$ & {$[131,310,311]$} \\
\hline & E2 & UBC9 & Overexpression & $\begin{array}{l}\text { Breast, prostate, } \\
\text { pancreatic, } \\
\text { osteosarcoma, } \\
\text { hepatocellular }\end{array}$ & {$[310,312,313]$} \\
\hline & \multirow{3}{*}{ E3 } & \multirow[b]{2}{*}{ PIAS1 } & Underexpression & breast & [314] \\
\hline & & & Overexpression & $\begin{array}{l}\text { Prostate, } \\
\text { multiple } \\
\text { myeloma }\end{array}$ & [315-317] \\
\hline & & PIAS3 & Overexpression & colorectal & [310] \\
\hline \multirow[t]{2}{*}{ NEDD8 } & DUB & $\begin{array}{c}\mathrm{Jab} 1 / \mathrm{CSN} \\
5\end{array}$ & Overexpression & $\begin{array}{l}\text { Breast, ovarian, } \\
\text { hepatocellular, } \\
\text { NSCLC, Oral } \\
\text { squamous cell, } \\
\text { Laryngal, } \\
\text { thyroid, } \\
\text { pancreatic, } \\
\text { esophageal, } \\
\text { colorectal, } \\
\text { gastric }\end{array}$ & [318] \\
\hline & E3 & C-CBL & Underexpression & lung & [319] \\
\hline
\end{tabular}

Table 2: Dysregulation of UbL enzymes in cancer. This table summarizes the known dysregulations of these enzymes. It comprises the main enzymes in each pathway but is not necessarily exhaustive. 


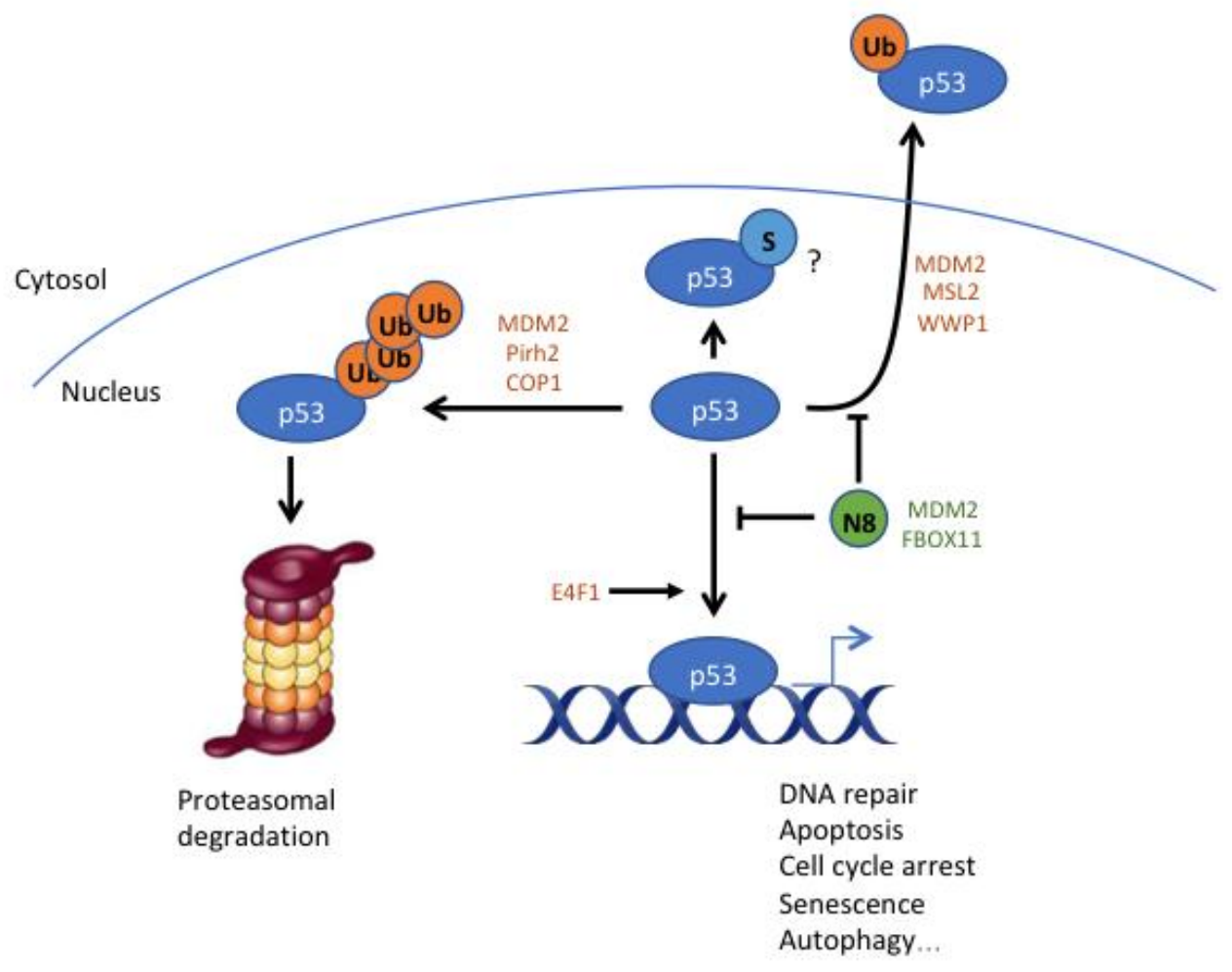

Figure 1: Regulation of p53 by UbL. N8: Nedd8, Ub: Ubiquitin, S: SUMO 